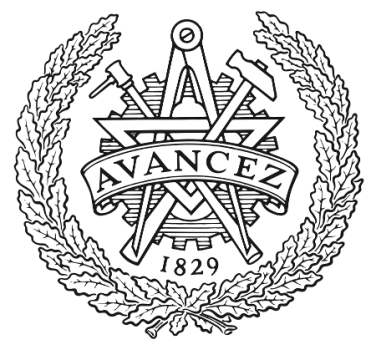

CHALMERS

UNIVERSITY OF TECHNOLOGY

\title{
Hydrogen-assisted SCR of NOx over alumina-supported silver and indium catalysts using C2-hydrocarbons and oxygenates
}

Downloaded from: https://research.chalmers.se, 2023-04-26 14:51 UTC

Citation for the original published paper (version of record):

Ström, L., Carlsson, P., Skoglundh, M. et al (2016). Hydrogen-assisted SCR of NOx over alumina-supported silver and indium catalysts using C2-hydrocarbons and oxygenates. Applied Catalysis B: Environmental, 181: 403-412. http://dx.doi.org/10.1016/j.apcatb.2015.08.009

N.B. When citing this work, cite the original published paper. 


\title{
Hydrogen-assisted SCR of $\mathrm{NO}_{x}$ over alumina-supported silver and indium catalysts using $\mathrm{C}_{2}$-hydrocarbons and oxygenates
}

\author{
Linda Ström*, Per-Anders Carlsson, Magnus Skoglundh and Hanna Härelind \\ Competence Centre for Catalysis \\ Department of Chemistry and Chemical Engineering \\ Chalmers University of Technology \\ SE-412 96 Göteborg \\ Sweden \\ *Corresponding author: linda.strom@chalmers.se, +46 317722907
}

\begin{abstract}
This work focuses on the selective catalytic reduction (SCR) of nitrogen oxides $\left(\mathrm{NO}_{\mathrm{x}}\right)$ with ethane, ethene, acetic acid, dimethyl ether (DME) and ethanol, respectively, over alumina-supported silver and indium catalysts. The impact of hydrogen and the nature of the reductant on the catalyst structure and SCR activity are studied. The ability to reduce $\mathrm{NO}_{x}$ differs significantly among the studied reductants, but also between the two catalysts, of which $\mathrm{Ag} / \mathrm{Al}_{2} \mathrm{O}_{3}$ is the overall most active catalyst. However, the $\mathrm{In} / \mathrm{Al}_{2} \mathrm{O}_{3}$ catalyst exhibits high SCR activity with DME as reductant in contrast to the $\mathrm{Ag} / \mathrm{Al}_{2} \mathrm{O}_{3}$ catalyst, which shows negligible activity. We attribute this difference to the higher number of acidic sites on the $\mathrm{In} / \mathrm{Al}_{2} \mathrm{O}_{3}$ catalyst and the higher degree of DME combustion over $\mathrm{Ag} / \mathrm{Al}_{2} \mathrm{O}_{3}$. Moreover, the number of sites that previously have been identified to promote hydrocarbon activation, i.e. silver cluster sites $\left(\mathrm{Ag}_{\mathrm{n}}{ }^{\delta+}\right)$ in $\mathrm{Ag} / \mathrm{Al}_{2} \mathrm{O}_{3}$ catalysts and indium cluster sites $\left(\mathrm{In}^{3+}\right)$ in $\mathrm{In} / \mathrm{Al}_{2} \mathrm{O}_{3}$ catalysts, are shown to increase upon addition of small amounts of hydrogen in the feed. We suggest that the increased SCR activity over $\mathrm{In} / \mathrm{Al}_{2} \mathrm{O}_{3}$ originates from an increased number of sites for activation of hydrocarbons, analogous to previous proposals for Ag-based catalysts, in combination with a direct effect on the reaction mechanism.
\end{abstract}

Keywords: Lean $\mathrm{NO}_{x}$ reduction, Silver-alumina, Indium-alumina, HC-SCR, Hydrogenassistance

\section{Introduction}

Global warming is considered the modern time's most serious climate threat [1]. For the transport sector, this pushes the development of more fuel-efficient vehicles. Engine combustion in oxygen excess, so-called lean combustion, provides one route towards reduced fuel consumption. However, the exhausts from lean combustion contain a large surplus of oxygen, which prevents the reduction of nitrogen oxides $\left(\mathrm{NO}_{\mathrm{x}}\right)$ using conventional three-way catalysis. Among the most promising techniques for lean $\mathrm{NO}_{\mathrm{x}}$ reduction one finds selective catalytic reduction (SCR) with ammonia $\left(\mathrm{NH}_{3}\right)$ or hydrocarbons (HC) as reductant for $\mathrm{NO}_{x}$. For heavy-duty vehicles, $\mathrm{NH}_{3}-\mathrm{SCR}$ is today implemented, using urea-water solutions as the source of ammonia. However, urea- 
SCR may cause ammonia slip and for light-duty vehicles drawbacks of this technique include the heavy urea tank required in addition to the complex and costly injection system [2]. The advantage of HC-SCR is that the fuel can be used as the hydrocarbon reductant and injected directly and thus the need of a separate tank for the reductant is avoided.

Alumina-based catalysts have received much attention thanks to their high stability under hydrothermal conditions. In the case of lean $\mathrm{NO}_{\mathrm{x}}$ reduction, silver-alumina $\left(\mathrm{Ag} / \mathrm{Al}_{2} \mathrm{O}_{3}\right)$ has been found to exhibit SCR activity both with ammonia [3-5] and hydrocarbons [6-10] as reducing agent. Another alumina-based catalyst that has received attention is indium-alumina $\left(\mathrm{In} / \mathrm{Al}_{2} \mathrm{O}_{3}\right)$ [11-18], which shows high resistance to water and sulphur dioxide $\left(\mathrm{SO}_{2}\right)$ in lean conditions.

The reaction scheme of lean $\mathrm{NO}_{\mathrm{x}}$ reduction with hydrocarbons is still not fully understood. Over $\mathrm{Ag} / \mathrm{Al}_{2} \mathrm{O}_{3}$ the following reactions are proposed; i) Oxidation of NO to $\mathrm{NO}_{2}$ followed by formation of surface nitrites and nitrates, $i$ ) adsorption and partial oxidation of hydrocarbons, and iii) surface reactions between the adsorbed nitrogen species and the partially oxidized hydrocarbons [19]. Also over $\mathrm{In} / \mathrm{Al}_{2} \mathrm{O}_{3}, \mathrm{NO}$ oxidation to $\mathrm{NO}_{2}$ has been proposed to play an important role and surface nitrates have been suggested to be key intermediates in the overall reaction [13].

In addition to the inherent properties of the catalyst, HC-SCR of $\mathrm{NO}_{\mathrm{x}}$ is also dependent on the nature of the reducing agent. Parameters such as partial oxidation of the reductant, which in turn is dependent on the nature of the $\mathrm{C}-\mathrm{H}$ (or $\mathrm{C}-\mathrm{C}$ ) bonds, accessibility of $\pi$-electrons, molecular orientation (steric effects) and sticking probability of the reductant are identified as critical factors [10, 20].

Furthermore, the catalytic reduction of $\mathrm{NO}_{x}$ with hydrocarbons over $\mathrm{Ag} / \mathrm{Al}_{2} \mathrm{O}_{3}$ can be increased by the introduction of hydrogen. This phenomenon is referred to as 'the hydrogen effect' and has been described by several research groups [3, 21-30]. The effect is reversible so that addition/removal of hydrogen from the feed increases/decreases the SCR activity instantly. Such cycles can be repeated without loss in catalytic performance $[24,26]$. In the open literature, the origin of the hydrogen effect is extensively debated. The main suggestions involve reduction of adsorbed nitrogen species [27-30], enhanced activation of the hydrocarbon [4, 22, 26, 30, 31], modification of the Ag-species [4, 26, 30,31], as well as direct effects on the reaction mechanism [30, 32]. For $\mathrm{In} / \mathrm{Al}_{2} \mathrm{O}_{3}$, a minor hydrogen effect has previously been reported during $\mathrm{NH}_{3}-\mathrm{SCR}$ [33].

The present study focuses on lean $\mathrm{NO}_{\mathrm{x}}$ reduction over $\mathrm{Ag} / \mathrm{Al}_{2} \mathrm{O}_{3}$ and $\mathrm{In} / \mathrm{Al}_{2} \mathrm{O}_{3}$ using different types of $\mathrm{C}_{2}$-based reductants, also including the hydrogen effect. The $\mathrm{C}_{2}-$ reductants are also used as probe molecules to examine the active sites for activation of the reducing agent. For this purpose, a $2 \mathrm{wt} \% \mathrm{Ag} / \mathrm{Al}_{2} \mathrm{O}_{3}$ catalyst is compared to an $\mathrm{In} / \mathrm{Al}_{2} \mathrm{O}_{3}$ catalyst containing the same molar amount of metal. The catalytic performance for lean $\mathrm{NO}_{\mathrm{x}}$ reduction is evaluated using five different hydrocarbons and oxygenates based on two carbons; ethane, ethene, acetic acid, dimethyl ether (DME) and ethanol. The effect of addition of small amounts of hydrogen to the feed is also evaluated. The crystal structure and surface acidity are investigated using XRD and $\mathrm{NH}_{3}$-TPD, respectively. Moreover, diffuse reflectance UV-Vis spectroscopy is used to characterize the type of silver and indium species as a function of the surrounding gas phase, i.e. both fresh samples and samples exposed to ethene, DME or hydrogen, respectively, are examined.

\section{Materials and methods}




\subsection{Catalyst preparation and basic characterization}

The $\mathrm{Ag} / \mathrm{Al}_{2} \mathrm{O}_{3}$ and $\mathrm{In} / \mathrm{Al}_{2} \mathrm{O}_{3}$ catalysts were prepared by incipient wetness impregnation of $\gamma-\mathrm{Al}_{2} \mathrm{O}_{3}$ (PURALOX ${ }^{\circledR} \mathrm{SBa} 200$, Sasol) using silver nitrate $(\geq 99.0 \%$ Sigma-Aldrich) and indium nitrate hydrate (99.99\% Sigma Aldrich) as the active phase precursor, respectively. The targeting Ag loading was $2 \mathrm{wt} \%$ and the In loading corresponded to the equivalent molar amount, giving a targeted In loading of $2.1 \mathrm{wt} \%$. After impregnation, the powder samples were frozen with liquid nitrogen, subsequently freeze-dried and thereafter calcined in air at $600^{\circ} \mathrm{C}$ for four hours. Monoliths with 188 channels (400 CPSI, $\varnothing=20 \mathrm{~mm}, \mathrm{~L}=20 \mathrm{~mm}$ ) were cut from a commercial cordierite honeycomb structure (Corning) and calcined in air at $600^{\circ} \mathrm{C}$ for one hour. Washcoat slurries were prepared, containing binder agent (DISPERAL ${ }^{\circledR} \mathrm{P} 2$, Sasol) and one of the powder catalysts (ratio 1:4) in 1:1-ratio ethanol-water solutions. Monoliths were dipped into the slurries, gently shaken for removal of excess slurry, dried in a $90^{\circ} \mathrm{C}$ hot air stream and subsequently calcined at $500^{\circ} \mathrm{C}$ for 3 minutes. The coating procedure was repeated until the washcoat mass corresponded to $20 \%$ of the coated monolith mass. Finally, the monoliths were calcined in air at $600^{\circ} \mathrm{C}$ for one hour.

The catalyst samples were characterized with respect to surface area, surface acidity and particle size of the crystal phase. The specific surface area of the powder samples was determined using $\mathrm{N}_{2}$ physisorption according to the BET method [34] using a Micrometrics $\operatorname{TriStar}^{\circledR} 3000$ instrument. Prior to the $\mathrm{N}_{2}$ adsorption, the samples were thermally dried in vacuum at $200^{\circ} \mathrm{C}$. The specific surface area of $\gamma-\mathrm{Al}_{2} \mathrm{O}_{3}$ was measured to $197 \mathrm{~m}^{2} / \mathrm{g}$ and the decrease in surface area after impregnation is regarded negligible ( 185 and $188 \mathrm{~m}^{2} / \mathrm{g}$ for $\mathrm{Ag} / \mathrm{Al}_{2} \mathrm{O}_{3}$ and $\mathrm{In} / \mathrm{Al}_{2} \mathrm{O}_{3}$, respectively). Moreover, the density and strength of the acidic sites of the samples were characterized by temperature programmed desorption (TPD) of $\mathrm{NH}_{3}$, using the flow reactor described below. Prior to the $\mathrm{NH}_{3}$ adsorption, the sample was pretreated in $10 \% \mathrm{O}_{2}(20 \mathrm{~min})$ to remove carbonaceous matter, flushed with argon (5 min) and then exposed to $1000 \mathrm{ppm} \mathrm{H}_{2}(20$ $\min )$ at $550^{\circ} \mathrm{C}$ to reduce the sample. Thereafter, the temperature was decreased to $100^{\circ} \mathrm{C}$ and the sample was exposed to $1000 \mathrm{ppm} \mathrm{NH} 3$ (Ar-balance) until saturation. Subsequently, the system was flushed with $\mathrm{Ar}$ to remove weakly bound $\mathrm{NH}_{3}$ and the temperature was linearly increased to $550^{\circ} \mathrm{C}\left(20^{\circ} \mathrm{C} / \mathrm{min}\right)$. The desorbed $\mathrm{NH}_{3}$ was measured by Fourier transform infrared (FTIR) spectroscopy (MKS 2030). The crystal phases of the samples were investigated by X-ray diffraction (XRD) using a Siemens D5000 X-ray diffractometer scanning $2 \theta$ from 5 to $65^{\circ}$ in the scan mode $0.02^{\circ}$, one second, with $\mathrm{Ni}$-filtered $\mathrm{Cu} \mathrm{K}_{\alpha}$ radiation.

\subsection{Catalytic performance}

The catalytic activity was evaluated during extinction ramps $\left(500\right.$ to $100^{\circ} \mathrm{C}$ by $10^{\circ} \mathrm{C} / \mathrm{min}$ ), using the flow reactor system previously described in detail by Kannisto et al. [35]. Briefly, the reactor chamber consists of an insulated horizontal quartz tube (L $=80 \mathrm{~cm}, \varnothing_{\mathrm{i}}=22 \mathrm{~mm}$ ) heated by a metal coil. The catalyst temperature is measured inside the sample and the reactor temperature is controlled $15 \mathrm{~mm}$ before the catalyst sample by K-type thermocouples. Uncoated monoliths $\left(\mathrm{L}=80 \mathrm{~cm}, \varnothing_{\mathrm{i}}=22 \mathrm{~mm}\right)$ were placed before and after the coated monolith to shield the thermocouple from heat radiation emitted by the heating coil as well as reduce axial radiation heat losses from the coated monolith sample [36]. The hydrocarbons and oxygenates used as reducing agents in this study were ethane $\left(\mathrm{H}_{3} \mathrm{C}-\mathrm{CH}_{3}\right)$, ethene $\left(\mathrm{H}_{2} \mathrm{C}=\mathrm{CH}_{2}\right)$, ethanol $\left(\mathrm{H}_{3} \mathrm{C}-\right.$ $\left.\mathrm{CH}_{2} \mathrm{OH}\right)$, acetic acid $\left(\mathrm{H}_{3} \mathrm{C}-\mathrm{CHOOH}\right)$ and DME $\left(\mathrm{H}_{3} \mathrm{C}-\mathrm{O}-\mathrm{CH}_{3}\right)$, respectively. In all experiments, the feed was composed of 500 ppm NO, 1500 ppm $\mathrm{C}_{2}$-hydrocarbon $(\mathrm{C} / \mathrm{N}$ 
ratio of 6 , in line with previous experience [35, 37]), $10 \% \mathrm{O}_{2}$ and $5 \% \mathrm{H}_{2} \mathrm{O}$, in the presence or absence of $1000 \mathrm{ppm} \mathrm{H}_{2}$. The total gas flow was $3500 \mathrm{ml} / \mathrm{min}$, which corresponds to a space velocity (GHSV) of $33,400 \mathrm{~h}^{-1}$. Ethanol and water were introduced to the reactor via a controlled evaporator mixer system (CEM, Bronkhorst Low $\Delta \mathrm{P}$ Hi-Tech), carried by Ar. The inlet feed gases were introduced and regulated by mass-flow controllers (Bronkhorst Hi-Tech) and the outlet gas flow was analyzed by a gas phase FTIR spectrometer (MKS 2030). Prior to each measurement, the sample was pretreated in $\mathrm{O}_{2}\left(10 \%\right.$, Ar balance) at $500^{\circ} \mathrm{C}$ for $30 \mathrm{~min}$. The experiments were repeated to confirm the reproducibility of all results reported.

\subsection{UV-Vis spectroscopy}

The catalyst samples were analyzed using ultraviolet-visible (UV-Vis) diffuse reflectance spectroscopy in order to characterize the type of silver- and indium species present in the samples. Spectra in the range 200-1500 nm were recorded using a Varian Cary 5000 UV-Vis-NIR spectrophotometer equipped with an external DRA-2500 unit. The reflectance spectra were recorded and the spectrum of the $\mathrm{Al}_{2} \mathrm{O}_{3}$ support was subtracted as part of the background. To investigate the influence of reaction conditions on the type of surface species and/or oxidation state, both fresh catalysts and samples exposed to either ethene (500 ppm, Ar balance), DME (500 ppm, Ar balance) or hydrogen (1000 ppm, Ar balance) for 30 minutes at $400^{\circ} \mathrm{C}$, were analyzed.

\section{Results}

\subsection{Catalyst characterization}

The X-ray diffractograms of the powder samples are shown in Fig. 1. The diffractograms for the different samples are quite similar and all XRD peaks are characteristic for $\gamma-\mathrm{Al}_{2} \mathrm{O}_{3}[38,39]$. No additional peaks, which can be attributed to other crystalline phases, such as e.g. silver or indium oxides, are observed. This indicates that no large, i.e. larger than 3-5 nm [40], particles of other crystalline phases than $\gamma-\mathrm{Al}_{2} \mathrm{O}_{3}$ are present in the samples.

The density and strength of acidic sites were examined by $\mathrm{NH}_{3}-\mathrm{TPD}$. Prior to the $\mathrm{NH}_{3}$ adsorption, the sample was pretreated in $10 \% \mathrm{O}_{2}(20 \mathrm{~min})$ to remove carbonaceous matter, flushed with argon (5 min) and then exposed to $1000 \mathrm{ppm} \mathrm{H}_{2}(20 \mathrm{~min})$ at $550^{\circ} \mathrm{C}$ to reduce the sample. As shown in Fig. 2, $\mathrm{NH}_{3}$ starts to desorb from both the $\mathrm{Ag} / \mathrm{Al}_{2} \mathrm{O}_{3}$ and the $\mathrm{In} / \mathrm{Al}_{2} \mathrm{O}_{3}$ sample at about $125^{\circ} \mathrm{C}$, peaking just above $200^{\circ} \mathrm{C}$. The $\mathrm{In} / \mathrm{Al}_{2} \mathrm{O}_{3}$ sample exhibits a somewhat broader signal. The total $\mathrm{NH}_{3}$ uptake and the BET surface areas of the samples are shown in Table 1.

Table 1: Surface area and the total uptake of $\mathrm{NH}_{3}$ during $\mathrm{NH}_{3}$-TPD.

\begin{tabular}{|l|l|l|l|}
\hline & $\mathrm{Ag} / \mathrm{Al}_{2} \mathrm{O}_{3}$ & $\mathrm{In} / \mathrm{Al}_{2} \mathrm{O}_{3}$ & $\mathrm{Al}_{2} \mathrm{O}_{3}$ \\
\hline Surface area $\left(\mathrm{m}^{2} / \mathrm{g}\right)$ & 185 & 188 & 197 \\
\hline $\begin{array}{l}\text { Total } \mathrm{NH}_{3} \text { uptake } \\
\text { (mole/kg } \\
\text { washcoat) }\end{array}$ & 0.14 & 0.18 & 0.22 \\
\hline
\end{tabular}

\subsection{Catalytic performance}

The $\mathrm{Ag} / \mathrm{Al}_{2} \mathrm{O}_{3}$ and $\mathrm{In} / \mathrm{Al}_{2} \mathrm{O}_{3}$ catalysts were evaluated for lean $\mathrm{NO}_{\mathrm{x}}$ reduction using ethane, ethene, ethanol, acetic acid and DME, respectively, as reductants. Also, the 
effect of addition of $1000 \mathrm{ppm}$ hydrogen on the lean $\mathrm{NO}_{\mathrm{x}}$ reduction was evaluated. The results of the $\mathrm{NO}_{\mathrm{x}}$ reduction activity experiments are shown in Fig. 3.

\subsubsection{The non-oxygenated hydrocarbons}

Among the reductants, the highest $\mathrm{NO}_{x}$ reduction is seen over the $\mathrm{Ag} / \mathrm{Al}_{2} \mathrm{O}_{3}$ catalyst for hydrogen-assisted ethane-SCR $\left(90 \%\right.$ at $500^{\circ} \mathrm{C}$, Fig. 3a), followed by hydrogen-assisted ethene-SCR over the same catalyst $\left(88 \%\right.$ at $500^{\circ} \mathrm{C}$, Fig. $\left.3 \mathrm{~b}\right)$. With these reductants, the effect of the addition of hydrogen is well pronounced over the $\mathrm{Ag} / \mathrm{Al}_{2} \mathrm{O}_{3}$ catalyst with an increase in the overall $\mathrm{NO}_{\mathrm{x}}$ reduction, an increase in the low-temperature activity and a broadening of the temperature window with $\mathrm{NO}_{x}$ reduction. For $\mathrm{In} / \mathrm{Al}_{2} \mathrm{O}_{3}$, the addition of hydrogen clearly promotes the reduction of $\mathrm{NO}_{\mathrm{x}}$ with ethane as reducing agent (Fig. 3a). Here, the $\mathrm{NO}_{x}$ reduction increases from 5 to $17 \%$ at $500{ }^{\circ} \mathrm{C}$ when hydrogen is introduced into the feed gas. The overall highest activity received over the $\mathrm{In} / \mathrm{Al}_{2} \mathrm{O}_{3}$ catalyst is found with ethene as reductant $\left(50 \% \mathrm{NO}_{\mathrm{x}}\right.$ reduction at $500^{\circ} \mathrm{C}$, Fig. $3 \mathrm{~b})$. The conversion of ethane during the experiment is presented in Fig. 4 together with the yields of $\mathrm{CO}$ and $\mathrm{CO}_{2}$. The conversion of this reductant is lower compared to ethene, which is shown in Fig. 5. In the latter figure it can also be seen that the total combustion (to $\mathrm{CO}_{2}$ ) is higher with ethene then with ethane (Fig. 4). Only small amounts (maximum $12 \mathrm{ppm}$ ) of $\mathrm{N}_{2} \mathrm{O}$ and negligible amounts of other byproducts are formed over the catalysts (not shown) using the non-oxygenated hydrocarbons.

\subsubsection{The oxygenated hydrocarbons}

Similar to the hydrogen-assisted ethane- and ethene-SCR, also SCR with acetic acid results in an increased low-temperature activity and a broadened temperature window with $\mathrm{NO}_{x}$ reduction in presence of hydrogen, over the $\mathrm{Ag} / \mathrm{Al}_{2} \mathrm{O}_{3}$ catalyst (Fig. 3c). In general, $\mathrm{NO}_{x}$ is reduced less efficiently over the $\mathrm{In} / \mathrm{Al}_{2} \mathrm{O}_{3}$ catalyst compared to the $\mathrm{Ag} / \mathrm{Al}_{2} \mathrm{O}_{3}$ catalyst. The conversion of acetic acid together with the $\mathrm{CO}$ and $\mathrm{CO}_{2}$-yields are shown in Fig. 6.

With DME as reducing agent (Fig. 3d), no reduction of $\mathrm{NO}_{\mathrm{x}}$ can be observed over the $\mathrm{Ag} / \mathrm{Al}_{2} \mathrm{O}_{3}$ catalyst, while the $\mathrm{NO}_{x}$ reduction reaches $45 \%$ at $365^{\circ} \mathrm{C}$ over the $\mathrm{In} / \mathrm{Al}_{2} \mathrm{O}_{3}$ catalyst. Over $\mathrm{In} / \mathrm{Al}_{2} \mathrm{O}_{3}$, DME is fully converted just above $200^{\circ} \mathrm{C}$ while the conversion for $\mathrm{Ag} / \mathrm{Al}_{2} \mathrm{O}_{3}$ is complete at $500^{\circ} \mathrm{C}$. However, $\mathrm{Ag} / \mathrm{Al}_{2} \mathrm{O}_{3}$ combust $\mathrm{DME}$ to a higher degree compared to $\mathrm{In} / \mathrm{Al}_{2} \mathrm{O}_{3}$, as shown in Fig. 7.

The $\mathrm{Ag} / \mathrm{Al}_{2} \mathrm{O}_{3}$ catalyst exhibits a broad $\mathrm{NO}_{x}$ reduction temperature window with ethanol (Fig. 3e), starting at $260^{\circ} \mathrm{C}\left(250^{\circ} \mathrm{C}\right.$ with hydrogen-assisted ethanol) and peaking at $82 \% \mathrm{NO}_{\mathrm{x}}$ reduction at $440^{\circ} \mathrm{C}$. Ethanol is fully converted around $350^{\circ} \mathrm{C}$ over both catalysts (see Fig. 8).

Fig. 9-11 show the byproducts formed by the oxygenated reductants, with the peak byproducts summarized in Table 2 .

Table 2: Peak byproducts (in ppm) formed by the oxygenated reductants in the SCR experiments.

\begin{tabular}{|c|c|c|c|c|c|c|}
\hline & \multicolumn{2}{|c|}{ Acetic acid $\left(+\mathrm{H}_{2}\right)$} & \multicolumn{2}{c|}{$\mathrm{DME}\left(+\mathrm{H}_{2}\right)$} & \multicolumn{2}{c|}{ Ethanol $\left(+\mathrm{H}_{2}\right)$} \\
\hline & $\mathrm{Ag} / \mathrm{Al}_{2} \mathrm{O}_{3}$ & $\mathrm{In} / \mathrm{Al}_{2} \mathrm{O}_{3}$ & $\mathrm{Ag} / \mathrm{Al}_{2} \mathrm{O}_{3}$ & $\mathrm{In} / \mathrm{Al}_{2} \mathrm{O}_{3}$ & $\mathrm{Ag} / \mathrm{Al}_{2} \mathrm{O}_{3}$ & $\mathrm{In} / \mathrm{Al}_{2} \mathrm{O}_{3}$ \\
\hline $\mathrm{C}_{2} \mathrm{H}_{5} \mathrm{OH}$ & $32(25)$ & $29(56)$ & $6(7)$ & $6(8)$ & - & - \\
\hline $\mathrm{CH}_{3} \mathrm{OH}$ & $<5(<5)$ & $<5(<5)$ & $88(84)$ & $974(991)$ & $23(19)$ & $35(33)$ \\
\hline $\mathrm{C}_{2} \mathrm{H}_{4} \mathrm{O}$ & $45(45)$ & $47(58)$ & $34(31)$ & $29(28)$ & $406(393)$ & $367(352)$ \\
\hline $\mathrm{CH}_{2} \mathrm{O}$ & $57(93)$ & $87(99)$ & $27(34)$ & $171(179)$ & $34(37)$ & $25(23)$ \\
\hline $\mathrm{C}_{2} \mathrm{H}_{4}$ & $5(<5)$ & $18(26)$ & $<5(<5)$ & $<5(<5)$ & $61(54)$ & $355(382)$ \\
\hline $\mathrm{CH}_{4}$ & $13(11)$ & $16(18)$ & $<5(<5)$ & $<5(<5)$ & $6(6)$ & $7(5)$ \\
\hline
\end{tabular}




\begin{tabular}{|c|c|c|c|c|c|c|}
\hline $\mathrm{N}_{2} \mathrm{O}$ & $<5(<5)$ & $<5(<5)$ & $<5(<5)$ & $15(14)$ & $9(14)$ & $6(6)$ \\
\hline $\mathrm{NH}_{3}$ & $28(24)$ & $24(27)$ & $<5(<5)$ & $<5(<5)$ & $114(121)$ & $22(12)$ \\
\hline
\end{tabular}

\subsection{UV-Vis spectroscopy}

Both fresh samples and samples pretreated in ethene, DME and hydrogen, respectively, were characterized by UV-Vis spectroscopy in order to investigate the influence of different reductants on the catalysts. The alumina-subtracted UV-Vis spectra obtained are shown in Fig. 12, where the top panel shows deconvoluted spectra of fresh (Fig. 12a) and pretreated $\mathrm{Ag} / \mathrm{Al}_{2} \mathrm{O}_{3}$ (Fig. 12b) samples. By deconvolution of the spectrum for the fresh $\mathrm{Ag} / \mathrm{Al}_{2} \mathrm{O}_{3}$ sample, a peak at $215 \mathrm{~nm}$ can be identified, which is attributed to the $4 \mathrm{~d}^{10}$ to $4 \mathrm{~d} 9 \mathrm{~s}^{1}$ transition of dispersed $\mathrm{Ag}^{+}$ions $[41,42]$. Furthermore, the peaks at 280 and $350 \mathrm{~nm}$ are assigned to small $\operatorname{Ag}_{\mathrm{n}}{ }^{\delta+}$ clusters [43] and peaks above $390 \mathrm{~nm}$ are attributed to metallic silver particles [37, 41, 42, 44]. After exposure to ethene, DME and hydrogen, the spectrum changes significantly (Fig. 12b). Ethene exposure results in somewhat increased signals at higher wavelengths $(450-600 \mathrm{~nm})$ and the formation of a peak around $240 \mathrm{~nm}$ indicates increased concentration of silver ions [37, 42]. On the contrary, both exposure to DME and hydrogen results in major peaks at higher wavelengths $(>300 \mathrm{~nm})$, corresponding to increased concentration of silver clusters and metallic silver particles [37, 41, 42, 44]. The deconvoluted UV-Vis spectrum of fresh $\mathrm{In} / \mathrm{Al}_{2} \mathrm{O}_{3}$ is shown in Fig. 12c. Here, major peaks are visible at 215, 290, 425, 495 and $600 \mathrm{~nm} . \mathrm{In}_{2} \mathrm{O}_{3}$ exhibits peaks in the range 200-450 nm [45, 46], therefore the peaks found in this region are tentatively attributed to $\mathrm{In}^{3+}$-ions. Pretreatment of the $\mathrm{In} / \mathrm{Al}_{2} \mathrm{O}_{3}$ sample with DME and hydrogen, respectively, results in increased and broadened peaks, centered around $215 \mathrm{~nm}$, compared to the fresh sample (Fig. 12d). Also, signals at higher wavelengths decrease. Pretreatment with ethene results in decreased signals at higher wavelengths and a peak around $300 \mathrm{~nm}$.

\section{Discussion}

Selective catalytic reduction of $\mathrm{NO}_{\mathrm{x}}$ with hydrocarbons over metal oxide catalysts proceeds via a number of interconnected reactions [19]. The complete reaction scheme is still under debate, however, it likely comprises oxidation of $\mathrm{NO}$ to $\mathrm{NO}_{2}$ with subsequent formation of surface nitrites and nitrates, activation of the hydrocarbon by partial oxidation and reduction of $\mathrm{NO}_{\mathrm{x}}$ by the partially oxidized hydrocarbon species [19]. The final reaction products are ideally $\mathrm{N}_{2}, \mathrm{H}_{2} \mathrm{O}$ and $\mathrm{CO}_{2}$. Hence, an efficient HCSCR catalyst should, in general, hold sites active for partial oxidation of hydrocarbons and sites where adsorbed nitrogen-containing species selectively can be reduced to $\mathrm{N}_{2}$. Over $\mathrm{Ag} / \mathrm{Al}_{2} \mathrm{O}_{3}$ catalysts, it has been suggested that metallic silver particles are active for total oxidation of the reductant by oxygen [47], whereas silver clusters provide sites for partial oxidation of the reductant by $\mathrm{NO}$ and/or oxygen, which form reductants activated for further reaction with NO, resulting in $\mathrm{N}_{2}$ [26]. Moreover, Shimizu et al. [48] demonstrated that the active sites for hydrocarbon activation vary as a function of the reaction conditions, especially with the type of reductant and reaction temperature.

For $\mathrm{In} / \mathrm{Al}_{2} \mathrm{O}_{3}$, Park et al. [18] proposed that well-dispersed indium oxide clusters activate the hydrocarbon that, with utilization of active alumina sites, selectively reduce $\mathrm{NO}_{\mathrm{x}}$ to $\mathrm{N}_{2}$. Moreover, they found that at higher indium-loadings ( $>5 \mathrm{wt} \%$ ), active sites on the alumina support become blocked, leading to a decrease in $\mathrm{NO}_{\mathrm{x}}$ reduction. 
In the current work, the effect of varying the structure of a reductant based on two carbons was investigated for lean $\mathrm{NO}_{x}$ reduction over $\mathrm{Ag} / \mathrm{Al}_{2} \mathrm{O}_{3}$ and $\mathrm{In} / \mathrm{Al}_{2} \mathrm{O}_{3}$, containing equivalent molar amounts of metal. The structure of the compared reductants ranged from saturated ethane to the simplest ether, DME. Furthermore, the physicochemical properties of the catalysts were characterized by $\mathrm{N}_{2}$ physisorption, $\mathrm{XRD}, \mathrm{NH}_{3}$-TPD and UV-Vis spectroscopy in order to investigate the nature of the catalysts in terms of surface area, particle size, surface acidity and oxidation states.

\subsection{UV-Vis spectroscopy}

The UV-Vis spectra obtained show that the nature of the silver species in the $\mathrm{Ag} / \mathrm{Al}_{2} \mathrm{O}_{3}$ sample ranges from isolated silver ions to metallic silver (see Fig 12). After pretreatment with hydrogen and DME, respectively, the absorption peaks shift towards higher wavelengths $(>300 \mathrm{~nm})$, attributed to silver clusters $\left(\mathrm{Ag}_{\mathrm{n}}{ }^{\delta+}\right)$ and metallic silver $\left(\mathrm{Ag}^{0}\right)$ [37, 41, 42, 44]. In addition, a small peak appears around $240 \mathrm{~nm}$ after pretreatment with ethene, which is attributed to silver ions [37, 42]. Furthermore, Lv et al. [45] experienced a gradual red-shift and broadening of the absorption edge of the UV-Vis spectra with increasing $\mathrm{In}_{2} \mathrm{O}_{3}$ concentration. In the present study, after pretreatment in hydrogen and DME, respectively, the UV-Vis spectra of indium exhibit broadenings and red-shifts of peaks at wavelengths around 200-300 $\mathrm{nm}$. This indicates that exposure of the $\mathrm{In} / \mathrm{Al}_{2} \mathrm{O}_{3}$ catalyst to hydrogen and DME may result in increased concentration of $\mathrm{In}_{2} \mathrm{O}_{3}$ clusters [45], which could provide active sites for hydrocarbon activation [18]. The results obtained in the current study indicate that, in the presence of hydrogen, the concentration of active sites for hydrocarbon activation increases. This may be the origin of the hydrogen effect, in agreement with what Shibata et al. [26] found for Ag-MFI. However, the reversibility of the hydrogen effect indicates that increased reductant activation is part of a dual explanation of the origin. It is therefore likely that hydrogen also affects the reaction mechanism (i.e. a chemical effect), as previously suggested $[30,32]$.

\subsection{Catalytic activity}

The conversion of the reducing agent during lean $\mathrm{NO}_{\mathrm{x}}$ reduction is shown in Fig. 48. For both samples, a clear trend can be seen where the conversion of the saturated hydrocarbon is low, the conversion of the unsaturated hydrocarbon is higher and the oxygenates are almost completely converted. However, the figures also show that the hydrocarbons are oxidized to a higher degree over the $\mathrm{Ag} / \mathrm{Al}_{2} \mathrm{O}_{3}$ catalyst than over $\mathrm{In} / \mathrm{Al}_{2} \mathrm{O}_{3}$, which in most cases form more $\mathrm{CO}$ (relatively). Moreover, the activity for $\mathrm{NO}_{\mathrm{x}}$ reduction varies considerably, both when comparing the reducing agents and when comparing the catalysts (Fig. 3).

\subsubsection{The non-oxygenated hydrocarbons as reductants}

With ethane and ethene as reductants, the conversion starts at relatively high temperatures and does not reach as high values as with ethanol as reductant. However, adding hydrogen to the feed results in equally high activity with ethane, ethene and ethanol (around 90\% $\mathrm{NO}_{\mathrm{x}}$ reduction), albeit still with a broader activity window with ethanol. The most pronounced hydrogen effect over the $\mathrm{In} / \mathrm{Al}_{2} \mathrm{O}_{3}$ catalyst can be observed with ethane, whereas almost no activity is shown for this reductant in absence of hydrogen.

In the case of SCR by alkenes over $\mathrm{Ag} / \mathrm{Al}_{2} \mathrm{O}_{3}, \mathrm{Ag}^{+}$-ions or $\mathrm{Ag}^{+}$-containing species are the active sites for hydrocarbon activation. Since alkane-SCR proceeds at higher 
temperatures, because of the lower reactivity of alkanes compared to alkenes, Agclusters $\left(\mathrm{Ag}_{\mathrm{n}}{ }^{\delta+}\right)$ are assumed to be responsible for hydrocarbon activation in this case [48], this can be due to that $\operatorname{Ag}_{n}{ }^{\delta+}$ can polarize the saturated hydrocarbon, facilitating partial oxidation.

The UV-Vis spectra indicate that the concentration of sites, active for hydrocarbon activation [18], increases when hydrogen and DME is present in the feed. Since ethane is more difficult to activate compared to ethene [48], this indicates that the role of hydrogen over the $\mathrm{In} / \mathrm{Al}_{2} \mathrm{O}_{3}$ catalyst could be to increase the hydrocarbon activation. Enhancement of hydrocarbon activation has previously been pointed out as a possible origin of the hydrogen effect over $\mathrm{Ag} / \mathrm{Al}_{2} \mathrm{O}_{3}[4,22,30,31]$.

Comparing the $\mathrm{NO}_{\mathrm{x}}$ reduction by ethane and ethene over the two catalysts (see Fig. $3 \mathrm{a}-\mathrm{b}$ ), it is clear that ethene shows the higher $\mathrm{NO}_{\mathrm{x}}$ reduction for both catalysts when hydrogen is absent. However, the addition of hydrogen in the feed makes ethane reduce $\mathrm{NO}_{x}$ more efficiently at lower temperatures compared to ethene over $\mathrm{Ag} / \mathrm{Al}_{2} \mathrm{O}_{3}$. Also over $\mathrm{In} / \mathrm{Al}_{2} \mathrm{O}_{3}$, the hydrogen effect is more pronounced when ethane is the reductant. Over this catalyst, the reductant conversion plots (Fig. 4-5) show that ethane stays almost completely intact during the experiment while ethene is up to $60 \%$ combusted. This indicates that $\mathrm{In} / \mathrm{Al}_{2} \mathrm{O}_{3}$ is not active enough for hydrocarbon activation to reduce $\mathrm{NO}_{x}$ by ethane in the examined temperature range.

\subsubsection{Acetic acid as the reductant}

Albeit the similar chemical structure, conversion of acetic acid starts at a higher temperature compared to ethanol, as seen when comparing Fig. 6 and Fig. 8. The latter figure shows that the conversion of acetic acid is very low over both catalysts when hydrogen is absent until the temperature reach about $400^{\circ} \mathrm{C}$, where it increase rapidly to $80 \%$ conversion. The addition of hydrogen promotes the acetic acid conversion over $\mathrm{Ag} / \mathrm{Al}_{2} \mathrm{O}_{3}$ and Fig. $3 \mathrm{c}$ also shows a significant hydrogen effect over this catalyst.

\subsubsection{DME as the reductant}

The two different catalysts show rather different activity for lean $\mathrm{NO}_{\mathrm{x}}$ reduction with DME as reductant. Over the $\mathrm{In} / \mathrm{Al}_{2} \mathrm{O}_{3}$ catalyst the maximum conversion of $\mathrm{NO}_{x}$ is $45 \%$ whereas no $\mathrm{NO}_{x}$ conversion at all can be observed over the $\mathrm{Ag} / \mathrm{Al}_{2} \mathrm{O}_{3}$ catalyst. It has been reported by Tamm et al. [50] that DME undergoes gas phase radical reactions with $\mathrm{NO}, \mathrm{O}_{2}$ and $\mathrm{H}_{2} \mathrm{O}$, which change the composition of the gas phase considerably before reaching the catalyst. A catalyst suited for DME-SCR should therefore have other properties than conventional HC-SCR catalysts; it should have a high capability to reduce $\mathrm{NO}_{x}$ using partially oxidized $\mathrm{C}_{1}$-hydrocarbons, not needing to be able to activate the hydrocarbon, and it should not unselectively oxidize species previously formed in the gas phase.

The high amount of methanol formed over the $\mathrm{In} / \mathrm{Al}_{2} \mathrm{O}_{3}$ catalyst in the present work (Fig. 10) is likely due to hydrolysis of DME to methanol according to reaction 1:

$$
\mathrm{H}_{3} \mathrm{C}-\mathrm{O}-\mathrm{CH}_{3}+\mathrm{H}_{2} \mathrm{O} \leftrightarrow 2 \mathrm{H}_{3} \mathrm{COH}
$$

Above $200^{\circ} \mathrm{C}$, the equilibrium of this reaction favors the formation of methanol with less than stoichiometric amount of water, whereas above $350^{\circ} \mathrm{C}$, the major part of the DME has already reacted in the gas phase and is therefore no longer available for hydrolysis over the catalyst [50].

DME gas phase reactions are initiated by the splitting of DME to an $\mathrm{H}_{3} \mathrm{CO}$ and a $\mathrm{CH}_{3} \cdot$ radical. The formation of $\mathrm{NO}_{2}$ is mainly due to the reactions of a $\mathrm{H}_{3} \mathrm{C}-\mathrm{O}-\mathrm{CH}_{2} \mathrm{OO}$. 
radical with $\mathrm{NO}$ [51]. Tamm et al. [52] compared $\mathrm{Ag} / \mathrm{Al}_{2} \mathrm{O}_{3}$ and $\mathrm{Al}_{2} \mathrm{O}_{3}$ for DME-SCR and found that the latter is less sensitive to the source of $\mathrm{NO}_{\mathrm{x}}\left(\mathrm{NO}\right.$ or $\left.\mathrm{NO}_{2}\right)$, while $\mathrm{NO}_{\mathrm{x}}$ reduction is more efficient with $\mathrm{NO}_{2}$ than $\mathrm{NO}$ over pure $\mathrm{Al}_{2} \mathrm{O}_{3}$.

Furthermore, UV-V is spectroscopy measurements in the present study show that DME changes the nature of the catalysts in similar ways as the presence of hydrogen (i.e. the $\mathrm{Ag} / \mathrm{Al}_{2} \mathrm{O}_{3}$ catalyst shows higher concentration of silver clusters and the $\mathrm{In} / \mathrm{Al}_{2} \mathrm{O}_{3}$ catalyst shows increased concentration of dispersed indium oxide clusters, when exposed to DME), and hence may increase the concentration of sites for hydrocarbon activation in the same way as hydrogen. DME is shown to reduce $\mathrm{NO}_{\mathrm{x}}$ relatively effectively over the $\mathrm{In} / \mathrm{Al}_{2} \mathrm{O}_{3}$ catalyst, which may be explained by an increased number of sites active for hydrocarbon activation. However, $\mathrm{Ag} / \mathrm{Al} \mathrm{O}_{3}$ is inherently more effective than $\mathrm{In} / \mathrm{Al}_{2} \mathrm{O}_{3}$ in hydrocarbon activation and, since it was indicated that the number of hydrocarbon-activating sites increases further, may result in deep oxidation of the sensitive DME, as supported by the analysis of Tamm et al. [50].

The $\mathrm{NH}_{3}$-TPD experiments in the present study show that the $\mathrm{In} / \mathrm{Al}_{2} \mathrm{O}_{3}$ catalyst exhibits a higher density of weak acidic sites compared to the $\mathrm{Ag} / \mathrm{Al}_{2} \mathrm{O}_{3}$ sample (see Fig. 2). It has been reported that catalysts that provide a high number of weak acidic sites are more efficient in DME-SCR [53]. Although the $\gamma-\mathrm{Al}_{2} \mathrm{O}_{3}$ sample in the current study exhibits a higher number of acidic sites than the $\mathrm{In} / \mathrm{Al}_{2} \mathrm{O}_{3}$ sample, Erkfeldt et al. [38] demonstrated that $\mathrm{In} / \mathrm{Al}_{2} \mathrm{O}_{3}$ has a higher activity for $\mathrm{NO}_{\mathrm{x}}$ reduction with DME than $\mathrm{In}_{2} \mathrm{O}_{3}$ or $\gamma-\mathrm{Al}_{2} \mathrm{O}_{3}$ alone. According to the authors, this promoting effect of In-doping could be owing to that $\mathrm{In}_{2} \mathrm{O}_{3}$ consumes a species which would otherwise inhibit the reaction, resulting in a more efficient reaction path or perhaps formation of additional or more active reaction sites.

\subsubsection{Ethanol as the reductant}

Over the $\mathrm{Ag} / \mathrm{Al}_{2} \mathrm{O}_{3}$ catalyst, the activity is highest and exhibits the broadest temperature window for $\mathrm{NO}_{\mathrm{x}}$ reduction with ethanol as reducing agent. Here, the addition of hydrogen in the feed facilitates the $\mathrm{NO}_{x}$ reduction. Over the $\mathrm{In} / \mathrm{Al}_{2} \mathrm{O}_{3}$ sample, the promoting effect of hydrogen is negligible. Furthermore, the introduction of hydrogen has previously been shown to facilitate the oxidation of $\mathrm{NO}$ to $\mathrm{NO}_{2}$ over $\mathrm{Ag} / \mathrm{Al}_{2} \mathrm{O}_{3}$. However, experiments with $\mathrm{NO}_{2}$ in the feed clarifies that this oxidation promotion by itself is not a significant factor for the hydrogen effect [24]. In the current work, it is observed that the addition of hydrogen promotes the oxidation of $\mathrm{NO}$ to $\mathrm{NO}_{2}$ over $\mathrm{In} / \mathrm{Al}_{2} \mathrm{O}_{3}$, however, in a less significant way compared to $\mathrm{Ag} / \mathrm{Al}_{2} \mathrm{O}_{3}$ and only when ethanol is the reductant (not shown).

During the $\mathrm{NO}_{x}$ reduction experiments, various $\mathrm{N}$ - and $\mathrm{C}$-containing species are detected in the outlet gas flow. Fig. 11 shows significant amounts of $\mathrm{NH}_{3}$ being formed over the $\mathrm{Ag} / \mathrm{Al}_{2} \mathrm{O}_{3}$ catalyst during ethanol-SCR. It is well known that $\mathrm{Ag} / \mathrm{Al}_{2} \mathrm{O}_{3}$ is highly active for $\mathrm{NH}_{3}-\mathrm{SCR}$ in the presence of $\mathrm{H}_{2}$, whereas this catalyst shows almost no activity for $\mathrm{NO}_{x}$ reduction in absence of $\mathrm{H}_{2}$. [32, 33]. Consequently, $\mathrm{NH}_{3}$ formed during the ethanol-SCR reaction should be able to act as a reducing agent itself and effectively reduce $\mathrm{NO}_{x}$ over $\mathrm{Ag} / \mathrm{Al}_{2} \mathrm{O}_{3}$ when hydrogen is present in the feed. However, the amount of $\mathrm{NH}_{3}$ formed over the catalyst is unaffected by the presence of hydrogen, which indicates that $\mathrm{NH}_{3}$ is not consumed as a reductant to a large extent in the presence of hydrogen, hence $\mathrm{NH}_{3}-\mathrm{SCR}$ is not an essential part of the ethanol-SCR reactions. This is in compliance with the findings by Pihl et al. [49]. Over the $\mathrm{In} / \mathrm{Al}_{2} \mathrm{O}_{3}$ catalyst, lower amounts of $\mathrm{NH}_{3}$ are formed during ethanol-SCR compared to over $\mathrm{Ag} / \mathrm{Al}_{2} \mathrm{O}_{3}$. However, only half the amount of $\mathrm{NH}_{3}$ is detected when $\mathrm{H}_{2}$ is added to the feed, and since 
$\mathrm{In} / \mathrm{Al}_{2} \mathrm{O}_{3}$ is inactive for $\mathrm{NH}_{3}-\mathrm{SCR}$ in absence of hydrogen [33], this indicates that $\mathrm{H}_{2}$ assisted $\mathrm{NH}_{3}-\mathrm{SCR}$ may be part of the ethanol-SCR reaction over the $\mathrm{In} / \mathrm{Al}_{2} \mathrm{O}_{3}$ catalyst in this study. Furthermore, almost 400 ppm ethene is detected during ethanol-SCR over $\mathrm{In} / \mathrm{Al}_{2} \mathrm{O}_{3}$, peaking around $450^{\circ} \mathrm{C}$. Since $\mathrm{In} / \mathrm{Al}_{2} \mathrm{O}_{3}$ is active for ethene-SCR in this temperature range, this may also be part of the ethanol-SCR reaction over $\mathrm{In} / \mathrm{Al}_{2} \mathrm{O}_{3}$.

\subsection{Summary}

In summary, the reductants compared in this study exhibit significant diversity in $\mathrm{NO}_{\mathrm{x}}$ reduction over $\mathrm{Ag} / \mathrm{Al}_{2} \mathrm{O}_{3}$ and $\mathrm{In} / \mathrm{Al}_{2} \mathrm{O}_{3}$. The promoting role of hydrogen has been shown to act via different routes in terms of how the active sites are affected, whereas the global effect is the same - an increase in the ability of the catalysts to activate the reductant, in combination with a direct effect on the reaction mechanism. Furthermore, the results presented in this work also suggest that $\mathrm{NH}_{3}-\mathrm{SCR}$ may play an important role in the $\mathrm{NO}_{x}$ reduction with ethanol over the $\mathrm{In} / \mathrm{Al}_{2} \mathrm{O}_{3}$ catalyst.

\section{Conclusions}

The significant diversity in activity for $\mathrm{NO}_{\mathrm{x}}$ reduction over the two alumina-based catalysts obtained for the five reductants demonstrates that, in order to achieve effective lean $\mathrm{HC}$-SCR of $\mathrm{NO}_{\mathrm{x}}$, the nature of both the reducing agent and the catalyst must be taken into account. Furthermore, this work identifies a similar role of hydrogen in $\mathrm{H}_{2}-$ assisted $\mathrm{HC}$-SCR over the $\mathrm{Ag} / \mathrm{Al}_{2} \mathrm{O}_{3}$ and $\mathrm{In} / \mathrm{Al}_{2} \mathrm{O}_{3}$ catalysts.

Over the $\mathrm{Ag} / \mathrm{Al}_{2} \mathrm{O}_{3}$ catalyst, the activity for $\mathrm{NO}_{x}$ reduction is highest with ethanol as the reducing agent, however, adding hydrogen to the feed causes equally high activity with ethane, ethene and ethanol, albeit with a broader activity window with ethanol. The $\mathrm{Ag} / \mathrm{Al}_{2} \mathrm{O}_{3}$ catalyst is shown to have no activity at all for $\mathrm{NO}_{\mathrm{x}}$ reduction using DME as reductant. Over the $\mathrm{In} / \mathrm{Al}_{2} \mathrm{O}_{3}$ catalyst, the highest $\mathrm{NO}_{\mathrm{x}}$ reduction is achieved with ethene as reducing agent followed by DME. The hydrogen assistance shows the highest effect with ethane. The considerably higher $\mathrm{NO}_{x}$ conversion with DME over $\mathrm{In} / \mathrm{Al}_{2} \mathrm{O}_{3}$ is likely owing to the higher number of acidic sites over this catalyst, in combination with a higher degree of DME combustion over $\mathrm{Ag} / \mathrm{Al}_{2} \mathrm{O}_{3}$.

By exposing the catalysts to low amounts of hydrogen, they both display an increase in sites that might be active for the hydrocarbon activation. Since hydrocarbon activation is recognized as a key reaction step in $\mathrm{HC}-\mathrm{SCR}$ of $\mathrm{NO}_{\mathrm{x}}$, this may explain the promoting effect of the addition of hydrogen, for both the $\mathrm{Ag} / \mathrm{Al}_{2} \mathrm{O}_{3}$ and the $\mathrm{In} / \mathrm{Al}_{2} \mathrm{O}_{3}$ catalyst, in combination with a direct effect on the reaction mechanism.

During ethanol-SCR over $\mathrm{Ag} / \mathrm{Al}_{2} \mathrm{O}_{3}$, significant amounts of $\mathrm{NH}_{3}$ are formed. Even though $\mathrm{H}_{2}$-assisted $\mathrm{NH}_{3}-\mathrm{SCR}$ is highly active over this catalyst, $\mathrm{NH}_{3}$ is not consumed in a large extent in this reaction when $\mathrm{H}_{2}$ is present. Hence, $\mathrm{NH}_{3}-\mathrm{SCR}$ is likely not an important reaction pathway for the ethanol-SCR reaction. However, over $\mathrm{In} / \mathrm{Al}_{2} \mathrm{O}_{3}$, significantly higher amounts of $\mathrm{NH}_{3}$ are detected in the absence compared to the presence of $\mathrm{H}_{2}$, during ethanol-SCR. Thus, $\mathrm{NH}_{3}-\mathrm{SCR}$ may in fact be part of the ethanol$\mathrm{SCR}$ reaction over $\mathrm{In} / \mathrm{Al}_{2} \mathrm{O}_{3}$.

\section{Acknowledgements}

This work has been financially supported by the Swedish Research Council and was performed within the Competence Centre for Catalysis, which is hosted by Chalmers 
University of Technology and financially supported by the Swedish Energy Agency and the member companies: AB Volvo, ECAPS AB, Haldor Topsøe A/S, Scania CV $\mathrm{AB}$, Volvo Car Corporation $\mathrm{AB}$ and Wärtsilä Finland $\mathrm{Oy}$.

\section{References}

[1] IPCC, T.F. Stocker, G.-K. D. Qin, M. Plattner, S.K. Tignor, J. Allen, A. Boschung, Y. Nauels, V. Xia, B. P.M., Midgley, Climate Change 2013: The Physical Science Basis. Contribution of Working Group I to the Fifth Assessment Report of the Intergovernmental Panel on Climate Change, Cambridge, United Kingdom and New York, NY, USA, 2013, p. 1535.

[2] E.C. Adams, M. Skoglundh, M. Folic, E.C. Bendixen, P. Gabrielsson, P.-A. Carlsson, Appl. Catal., B 165 (2015) 10-19.

[3] S. Tamm, S. Fogel, P. Gabrielsson, M. Skoglundh, L. Olsson, Appl. Catal., B 136 (2013) 168-176.

[4] K.-i. Shimizu, A. Satsuma, J. Phys. Chem. C 111 (2007) 2259-2264.

[5] S. Tamm, L. Olsson, S. Fogel, P. Gabrielsson, M. Skoglundh, AIChE J. 59 (2013) 4325-4333.

[6] T. Miyadera, Appl. Catal., B 2 (1993) 199-205.

[7] K. Masuda, K. Tsujimura, K. Shinoda, T. Kato, Appl. Catal., B 8 (1996).

[8] T. Miyadera, Appl. Catal., B 13 (1997) 157-165.

[9] K. Eranen, F. Klingstedt, K. Arve, L.E. Lindfors, D.Y. Murzin, J. Catal. 227 (2004) 328-343.

[10] H. Harelind, F. Gunnarsson, S.M.S. Vaghefi, M. Skoglundh, P.-A. Carlsson, ACS Catal. 2 (2012) 1615-1623.

[11] M. Haneda, Y. Kintaichi, N. Bion, H. Hamada, Appl. Catal., B 42 (2003).

[12] M. Haneda, E. Joubert, J.C. Menezo, D. Duprez, J. Barbier, N. Bion, M. Daturi, J. Saussey, J.C. Lavalley, H. Hamada, J. Mol. Catal. A: Chem. 175 (2001).

[13] J.H. Li, J.M. Hao, X.Y. Cui, L.X. Fu, Catal. Lett. 103 (2005).

[14] T. Maunula, Y. Kintaichi, M. Haneda, H. Hamada, Catal. Lett. 61 (1999).

[15] G.E. Marnellos, E.A. Efthimiadis, I.A. Vasalos, Appl. Catal., B 48 (2004).

[16] J.A. Perdigon-Melon, A. Gervasini, A. Auroux, J. Catal. 234 (2005).

[17] A.L. Petre, J.A. Perdigon-Melon, A. Gervasini, A. Auroux, Top. Catal. 19 (2002).

[18] P.W. Park, C.S. Ragle, C.L. Boyer, M.L. Balmer, M. Engelhard, D. McCready, J. Catal. 210 (2002) 97-105.

[19] R. Burch, Cat. Rev.- Sci. Eng. 46 (2004) 271-333.

[20] H. Kannisto, K. Arve, T. Pingel, A. Hellman, H. Harelind, K. Eranen, E. Olsson, M. Skoglundh, D.Y. Murzin, Catal. Sci. Tech. 3 (2013) 644-653.

[21] J.P. Breen, R. Burch, C. Hardacre, C.J. Hill, J. Phys. Chem. B 109 (2005) 48054807.

[22] S. Satokawa, J. Shibata, K. Shimizu, S. Atsushi, T. Hattori, Appl. Catal., B 42 (2003) 179-186.

[23] K.-i. Shimizu, A. Satsuma, Appl. Catal., B 77 (2007) 202-205.

[24] J.P. Breen, R. Burch, Top. Catal. 39 (2006) 53-58.

[25] S. Satokawa, Chem. Lett. (2000) 294-295.

[26] J. Shibata, Y. Takada, A. Shichi, S. Satokawa, A. Satsuma, T. Hattori, J. Catal. 222 (2004) 368-376.

[27] H. Kannisto, H.H. Ingelsten, M. Skoglundh, Top. Catal. 52 (2009). 
[28] N.A. Sadokhina, D.E. Doronkin, G.N. Baeva, S. Dahl, A.Y. Stakheev, Top. Catal. 56 (2013) 737-744.

[29] S. Tamm, N. Vallim, M. Skoglundh, L. Olsson, J. Catal. 307 (2013) 153-161.

[30] C. Thomas, Appl. Catal., B 162 (2015) 454-462.

[31] P.S. Kim, M.K. Kim, B.K. Cho, I.-S. Nam, S.H. Oh, J. Catal. 301 (2013) 65-

76.

[32] R. Burch, J.P. Breen, C.J. Hill, B. Krutzsch, B. Konrad, E. Jobson, L. Cider, K. Eranen, F. Klingstedt, L.E. Lindfors, Top. Catal. 30-1 (2004) 19-25.

[33] D.E. Doronkin, S. Fogel, S. Tamm, L. Olsson, T.S. Khan, T. Bligaard, P. Gabrielsson, S. Dahl, Appl. Catal., B 113 (2012) 228-236.

[34] S. Brunauer, P.H. Emmett, E. Teller, J. Am. Chem. Soc. 60 (1938) 309-319.

[35] H. Kannisto, X. Karatzas, J. Edvardsson, L.J. Pettersson, H.H. Ingelsten, Appl. Catal., B 104 (2011).

[36] C. Wang-Hansen, C.J. Kamp, M. Skoglundh, B. Andersson, P.-A. Carlsson, J. Phys. Chem. C 115 (2011) 16098-16108.

[37] M. Mannikko, M. Skoglundh, H.H. Ingelsten, Appl. Catal., B 119 (2012).

[38] S. Erkfeldt, M. Petersson, A. Palmqvist, Appl. Catal., B 117 (2012) 369-383.

[39] M. Boutros, J. Starck, B. de Tymowski, J.-M. Trichard, P. Da Costa, Top. Catal. 52 (2009).

[40] J.R. Anderson, K.C. Pratt, Introduction to characterization and testing of catalysts, Academic Press Inc., University of Melbourne, Australia, 1985.

[41] N. Bogdanchikova, F.C. Meunier, M. Avalos-Borja, J.P. Breen, A. Pestryakov, Appl. Catal., B 36 (2002) 287-297.

[42] A.N. Pestryakov, A.A. Davydov, J. Electron. Spectrosc. Relat. Phenom. 74 (1995) 195-199.

[43] K. Shimizu, J. Shibata, H. Yoshida, A. Satsuma, T. Hattori, Appl. Catal., B 30 (2001).

[44] X. She, M. Flytzani-Stephanopoulos, J. Catal. 237 (2006).

[45] J. Lv, T. Kako, Z. Li, Z. Zou, J. Ye, J. Phys. Chem. C 114 (2010) 6157-6162.

[46] X. Yang, J. Xu, T. Wong, Q. Yang, C.-S. Lee, Phys. Chem. Chem. Phys. 15 (2013) 12688-12693.

[47] F.C. Meunier, J.P. Breen, V. Zuzaniuk, M. Olsson, J.R.H. Ross, J. Catal. 187 (1999) 493-505.

[48] K. Shimizu, A. Satsuma, Phys. Chem. Chem. Phys. 8 (2006) 2677-2695.

[49] J.A. Pihl, T.J. Toops, G.B. Fisher, B.H. West, Catal. Today 231 (2014) 46-55.

[50] S. Tamm, H.H. Ingelsten, M. Skoglundh, A.E.C. Palmqvist, Appl. Catal., B 91 (2009).

[51] P. Dagaut, J. Luche, M. Cathonnet, Combust. Sci. Technol. 165 (2001) 61-84.

[52] S. Tamm, H.H. Ingelsten, M. Skoglundh, A.E.C. Palmqvist, Top. Catal. 52 (2009).

[53] S.G. Masters, D. Chadwick, Appl. Catal., B 23 (1999) 235-246. 


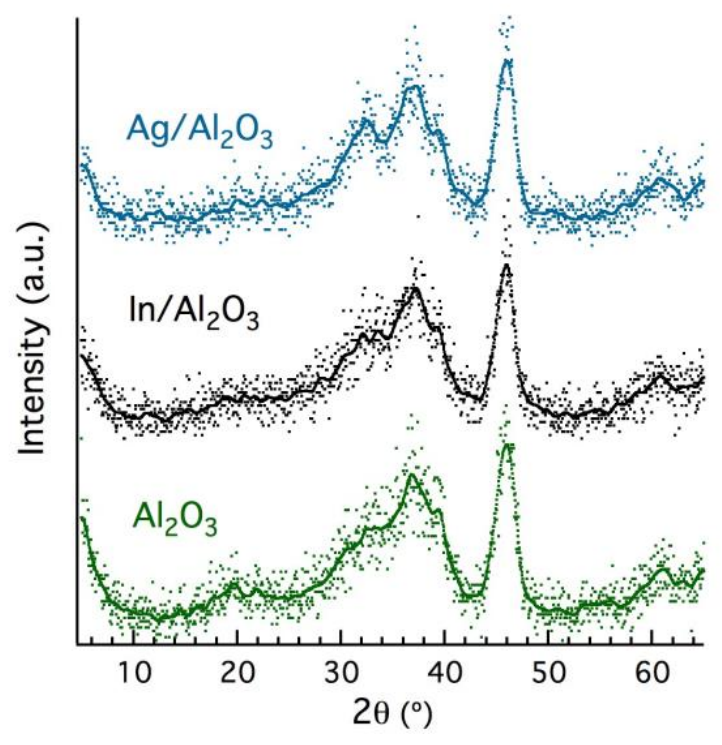

Fig. 1: XRD patterns for $\mathrm{Ag} / \mathrm{Al}_{2} \mathrm{O}_{3}, \mathrm{In} / \mathrm{Al}_{2} \mathrm{O}_{3}$ and $\gamma-\mathrm{Al}_{2} \mathrm{O}_{3}$. The floating median of the intensity in the diffractograms is represented by the solid line.

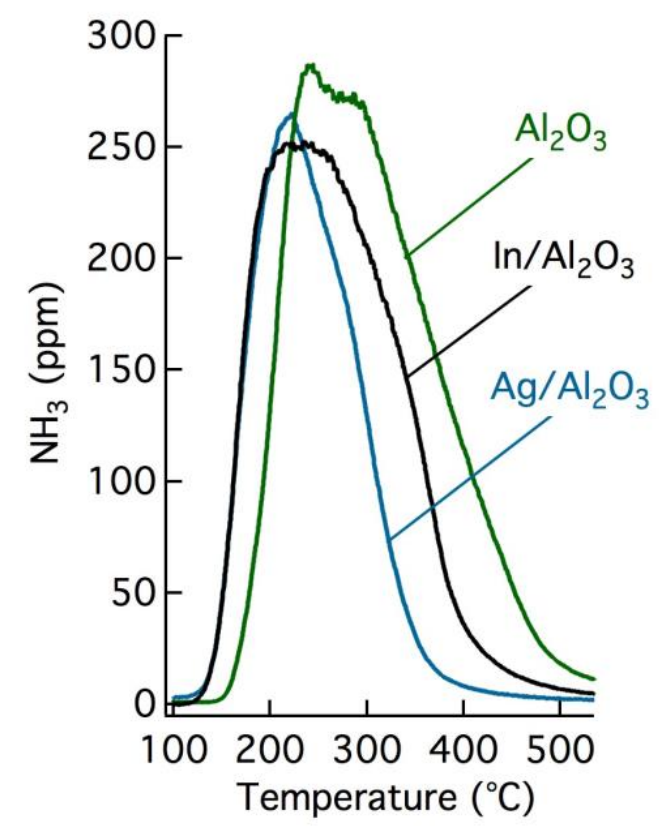

Fig. 2: $\mathrm{NH}_{3}-\mathrm{TPD}$ for $\mathrm{In} / \mathrm{Al}_{2} \mathrm{O}_{3}, \mathrm{Ag} / \mathrm{Al}_{2} \mathrm{O}_{3}$ and $\gamma-\mathrm{Al}_{2} \mathrm{O}_{3}$. The samples were exposed to $1000 \mathrm{ppm} \mathrm{NH}_{3}$ until saturation and, after removal of excess $\mathrm{NH}_{3}$, subsequently flushed with Ar while the temperature was linearly increased to $550^{\circ} \mathrm{C}\left(20^{\circ} \mathrm{C} / \mathrm{min}\right)$. 


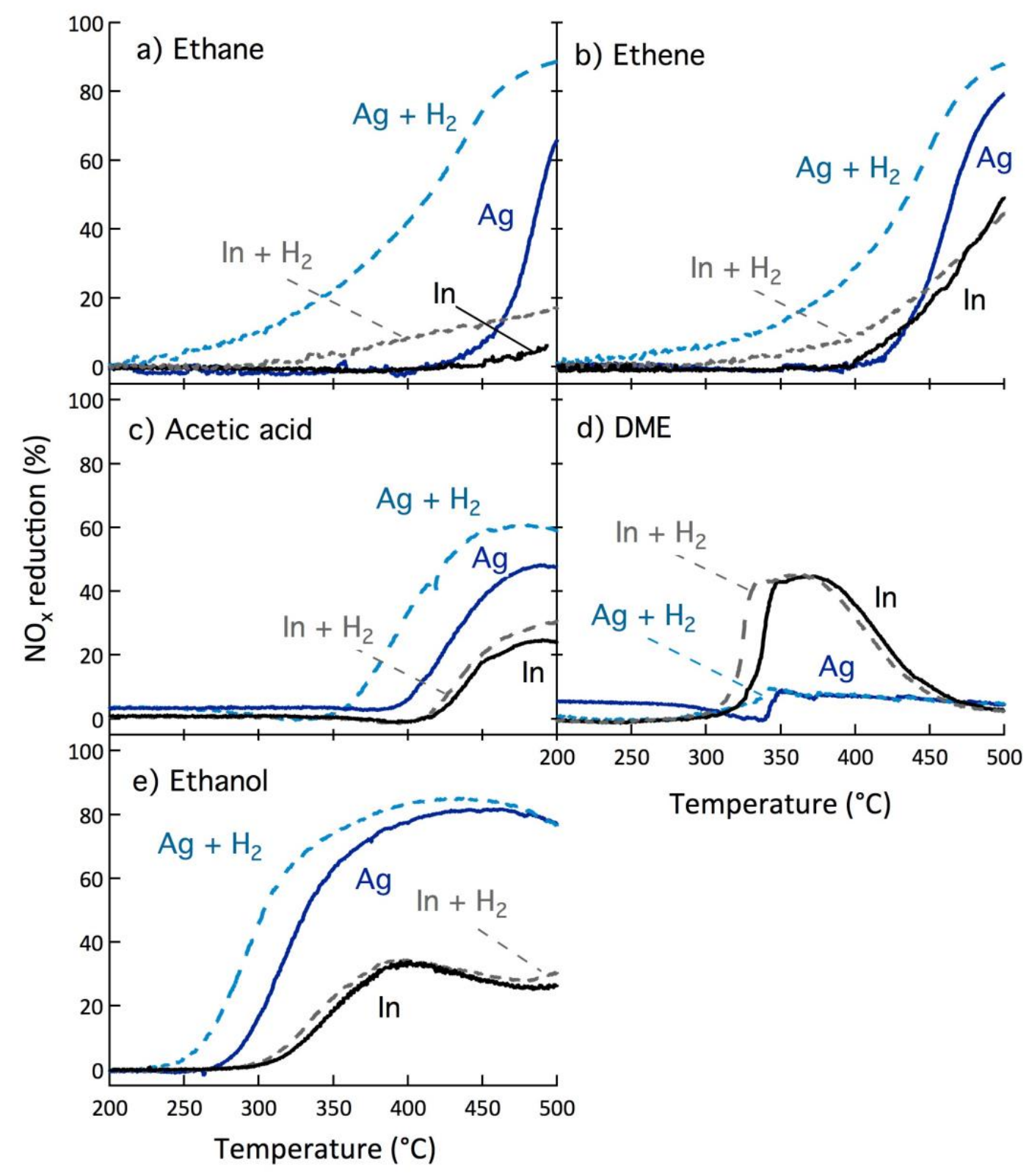

Fig. 3: Lean $\mathrm{NO}_{\mathrm{x}}$ reduction as a function of the catalyst temperature over $\mathrm{Ag} / \mathrm{Al}_{2} \mathrm{O}_{3}$ (dashed light blue lines are with the presence of $1000 \mathrm{ppm} \mathrm{H}_{2}$ and solid dark blue lines without the presence of $\mathrm{H}_{2}$ ), and $\mathrm{In} / \mathrm{Al}_{2} \mathrm{O}_{3}$ (dashed grey lines are with the presence of $1000 \mathrm{ppm} \mathrm{H}_{2}$ and solid black lines without the presence of $\mathrm{H}_{2}$ ) with a) ethane, b) ethene, c) acetic acid, d) DME and e) ethanol, as the reducing agent. Inlet gas composition: 500 ppm NO, 1500 ppm C $_{2}, 10 \% \mathrm{O}_{2}, 5 \% \mathrm{H}_{2} \mathrm{O}$, Ar-balance. C/N ratio of 6, GHSV $=33,400 \mathrm{~h}^{-1}$. 

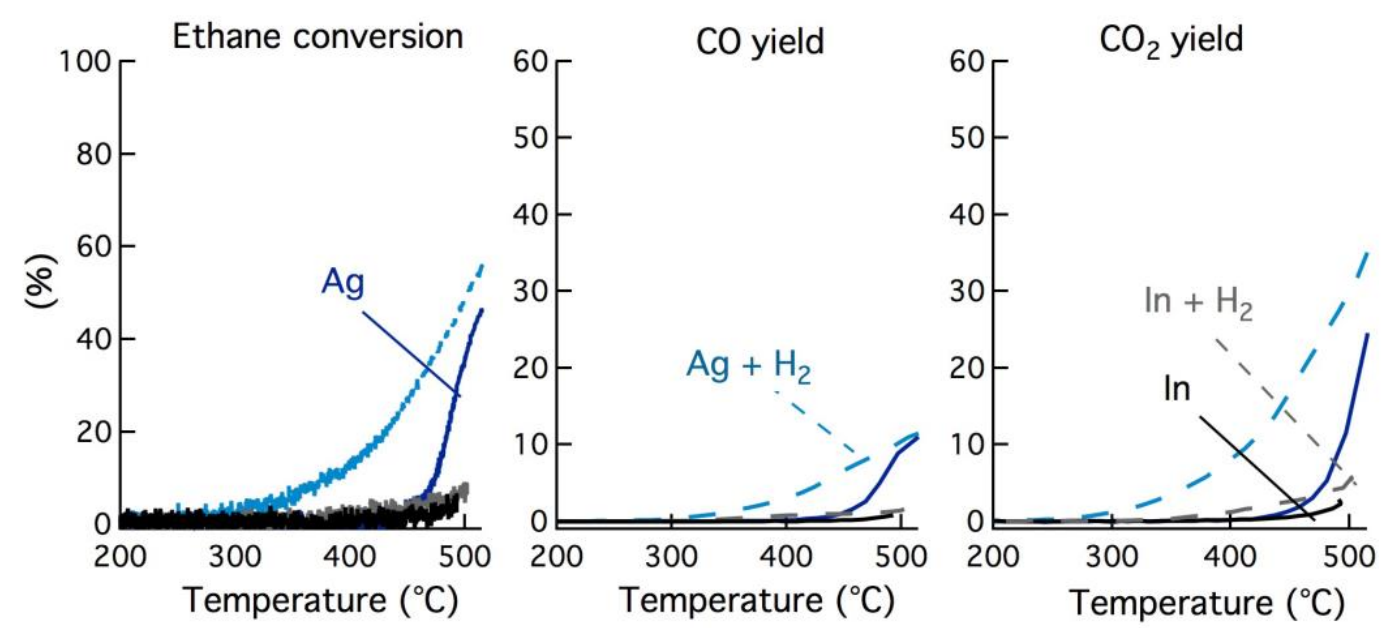

Fig. 4: Conversion of ethane, $\mathrm{CO}$-yield and $\mathrm{CO}_{2}$-yield as a function of the catalyst temperature over the $\mathrm{Ag} / \mathrm{Al}_{2} \mathrm{O}_{3}$ (dashed light blue lines are with the presence of $1000 \mathrm{ppm} \mathrm{H}_{2}$ and solid dark blue lines without the presence of $\mathrm{H}_{2}$ ), and $\mathrm{In} / \mathrm{Al}_{2} \mathrm{O}_{3}$ (dashed grey lines are with the presence of $1000 \mathrm{ppm} \mathrm{H}_{2}$ and solid black lines without the presence of $\mathrm{H}_{2}$ ) catalysts for the five reducing agents. Inlet gas composition: 500 ppm NO, 1500 ppm $_{2}, 10 \% \mathrm{O}_{2}, 5 \% \mathrm{H}_{2} \mathrm{O}$, Ar-balance. $\mathrm{C} / \mathrm{N}$ ratio of 6 , GHSV $=33,400 \mathrm{~h}^{-1}$.
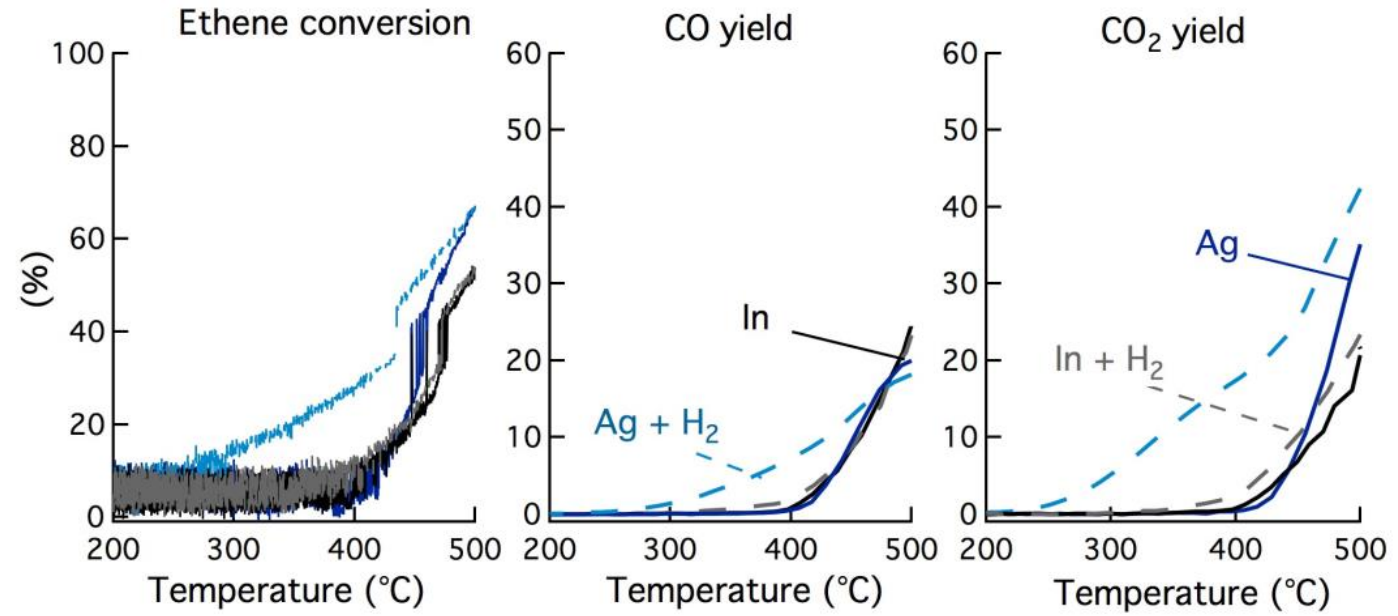

Fig. 5: Conversion of ethene, $\mathrm{CO}$-yield and $\mathrm{CO}_{2}$-yield as a function of the catalyst temperature over the $\mathrm{Ag} / \mathrm{Al}_{2} \mathrm{O}_{3}$ (dashed light blue lines are with the presence of $1000 \mathrm{ppm} \mathrm{H}_{2}$ and solid dark blue lines without the presence of $\mathrm{H}_{2}$ ), and $\mathrm{In} / \mathrm{Al}_{2} \mathrm{O}_{3}$ (dashed grey lines are with the presence of $1000 \mathrm{ppm} \mathrm{H}_{2}$ and solid black lines without the presence of $\mathrm{H}_{2}$ ) catalysts for the five reducing agents. Inlet gas composition: 500 ppm NO, $1500 \mathrm{ppm} \mathrm{C}_{2}, 10 \% \mathrm{O}_{2}, 5 \% \mathrm{H}_{2} \mathrm{O}$, Ar-balance. C/N ratio of 6 , GHSV $=33,400 \mathrm{~h}^{-1}$.
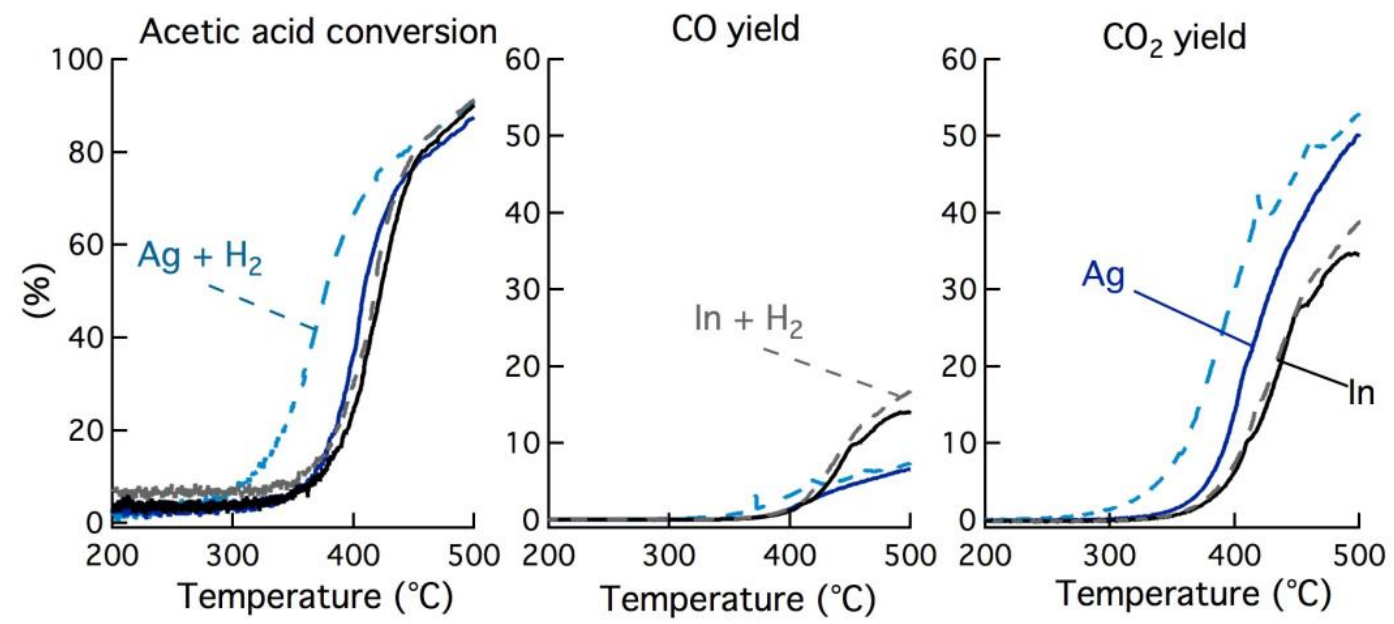
Fig. 6: Conversion of acetic acid, $\mathrm{CO}$-yield and $\mathrm{CO}_{2}$-yield as a function of the catalyst temperature over the $\mathrm{Ag} / \mathrm{Al}_{2} \mathrm{O}_{3}$ (dashed light blue lines are with the presence of $1000 \mathrm{ppm} \mathrm{H}$ and solid dark blue lines without the presence of $\mathrm{H}_{2}$ ), and $\mathrm{In} / \mathrm{Al}_{2} \mathrm{O}_{3}$ (dashed grey lines are with the presence of $1000 \mathrm{ppm} \mathrm{H}_{2}$ and solid black lines without the presence of $\mathrm{H}_{2}$ ) catalysts for the five reducing agents. Inlet gas composition: 500 ppm NO, 1500 ppm C $_{2}, 10 \% \mathrm{O}_{2}, 5 \% \mathrm{H}_{2} \mathrm{O}$, Ar-balance. C/N ratio of 6 , GHSV $=33,400 \mathrm{~h}^{-1}$.
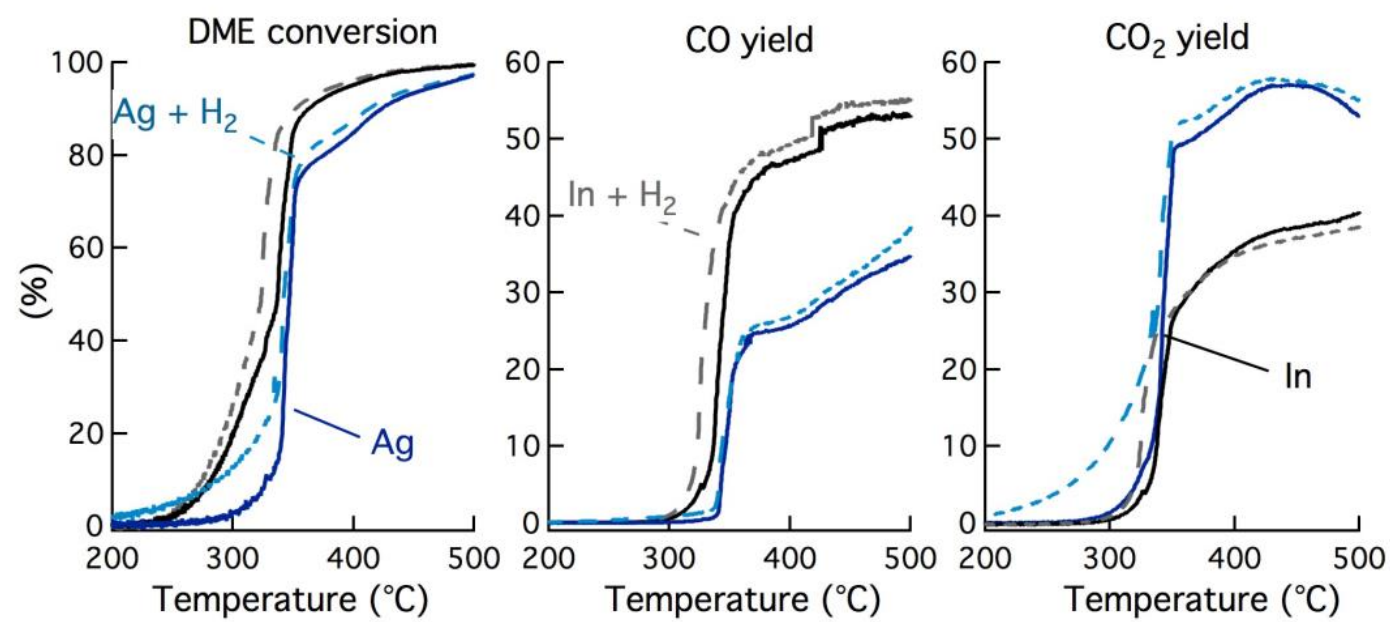

Fig. 7: Conversion of DME, CO-yield and $\mathrm{CO}_{2}$-yield as a function of the catalyst temperature over the $\mathrm{Ag} / \mathrm{Al}_{2} \mathrm{O}_{3}$ (dashed light blue lines are with the presence of $1000 \mathrm{ppm} \mathrm{H}_{2}$ and solid dark blue lines without the presence of $\mathrm{H}_{2}$ ), and $\mathrm{In} / \mathrm{Al}_{2} \mathrm{O}_{3}$ (dashed grey lines are with the presence of $1000 \mathrm{ppm} \mathrm{H}_{2}$ and solid black lines without the presence of $\mathrm{H}_{2}$ ) catalysts for the five reducing agents. Inlet gas composition: 500 ppm NO, 1500 ppm $_{2}, 10 \% \mathrm{O}_{2}, 5 \% \mathrm{H}_{2} \mathrm{O}$, Ar-balance. C/N ratio of 6 , GHSV $=33,400 \mathrm{~h}^{-1}$.
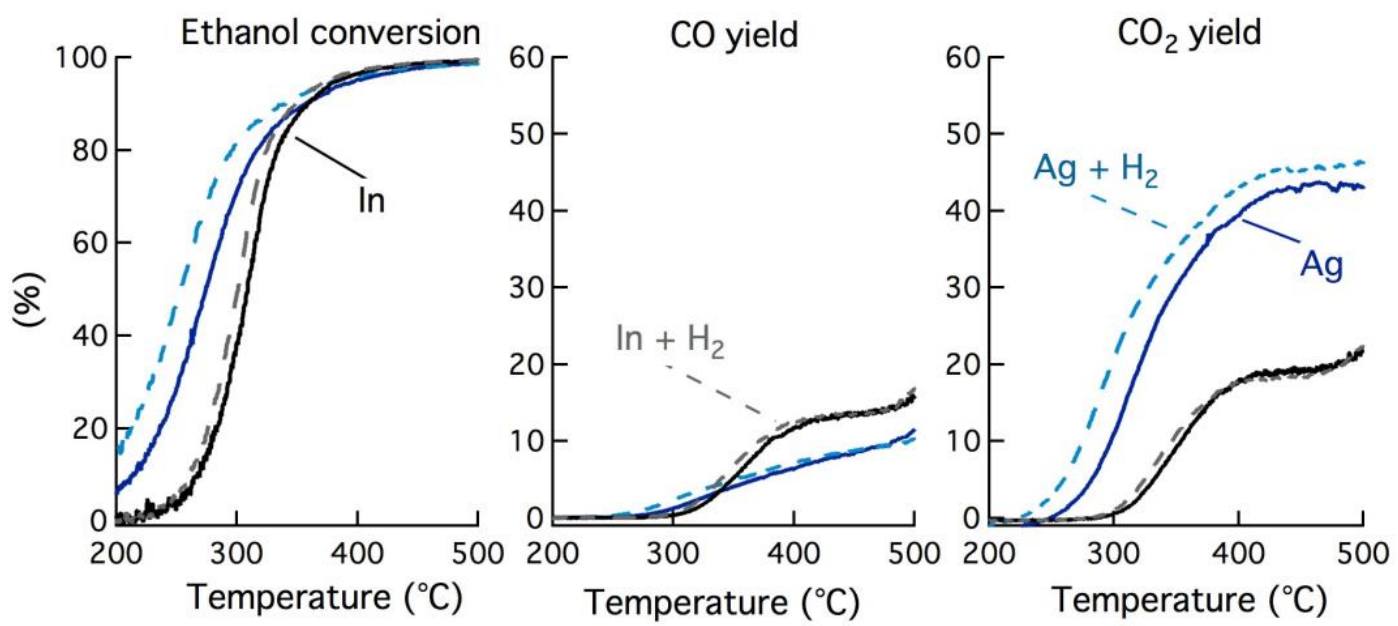

Fig. 8: Conversion of ethanol, $\mathrm{CO}$-yield and $\mathrm{CO}_{2}$-yield as a function of the catalyst temperature over the $\mathrm{Ag} / \mathrm{Al}_{2} \mathrm{O}_{3}$ (dashed light blue lines are with the presence of $1000 \mathrm{ppm} \mathrm{H}_{2}$ and solid dark blue lines without the presence of $\mathrm{H}_{2}$ ), and $\mathrm{In} / \mathrm{Al}_{2} \mathrm{O}_{3}$ (dashed grey lines are with the presence of $1000 \mathrm{ppm} \mathrm{H}_{2}$ and solid black lines without the presence of $\mathrm{H}_{2}$ ) catalysts for the five reducing agents. Inlet gas composition: 500 ppm NO, $1500 \mathrm{ppm} \mathrm{C}_{2}, 10 \% \mathrm{O}_{2}, 5 \% \mathrm{H}_{2} \mathrm{O}$, Ar-balance. C/N ratio of 6 , GHSV $=33,400 \mathrm{~h}^{-1}$. 


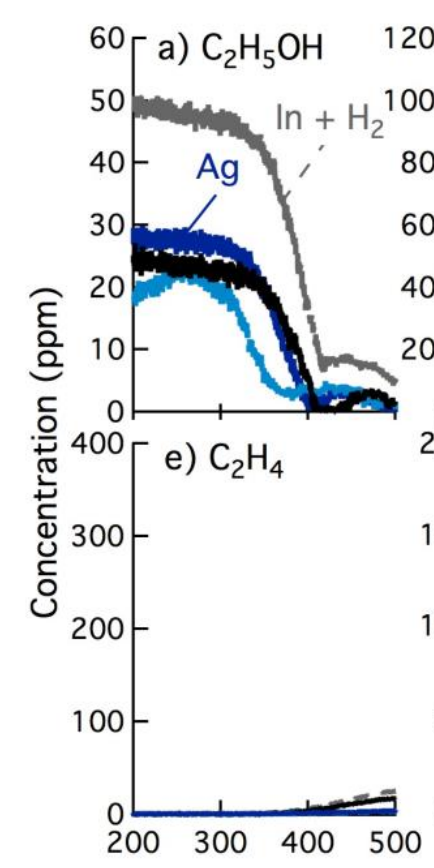

b) $\mathrm{CH}_{3} \mathrm{OH}$
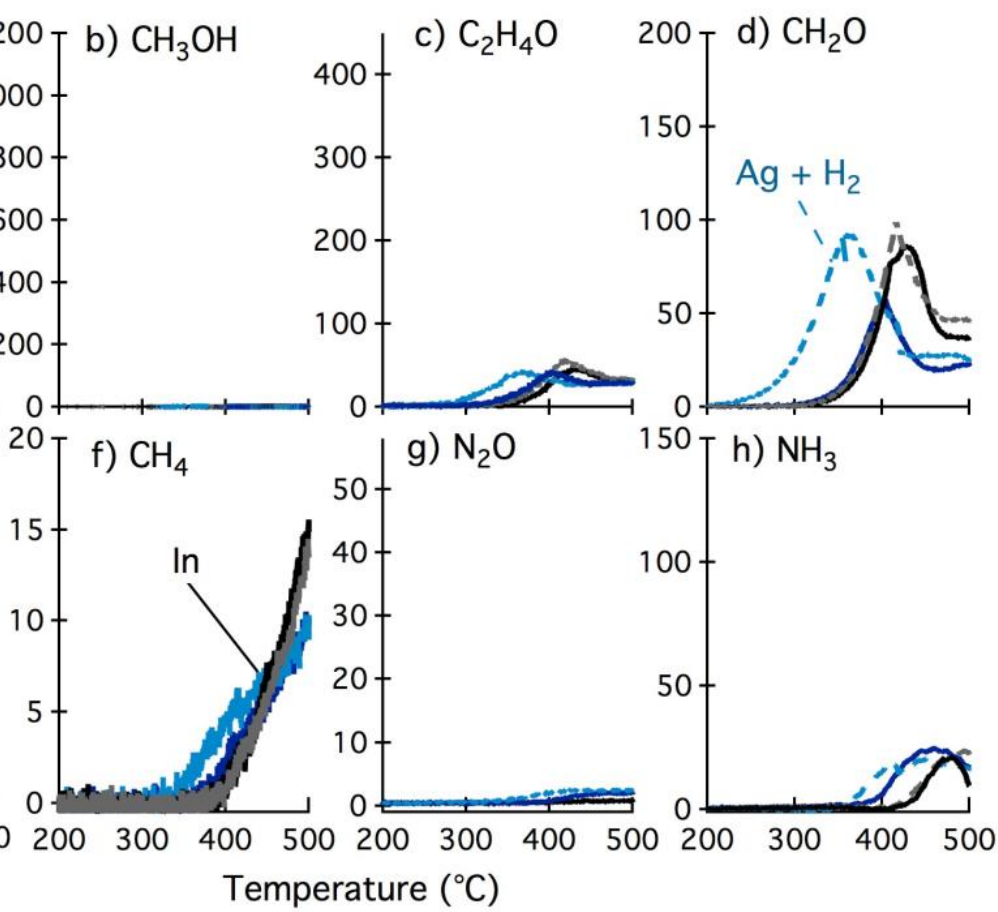

Fig. 9: SCR with acetic acid as reductant. Formation of a) ethanol, b) methanol, c) acetaldehyde, d) formaldehyde, e) ethene, f) methane, g) nitric oxide and $\mathrm{h}$ ) ammonia over $\mathrm{Ag} / \mathrm{Al}_{2} \mathrm{O}_{3}$ (dashed light blue lines are with the presence of $1000 \mathrm{ppm} \mathrm{H}_{2}$ and solid dark blue lines without the presence of $\mathrm{H}_{2}$ ), and $\mathrm{In} / \mathrm{Al}_{2} \mathrm{O}_{3}$ (dashed grey lines are with the presence of $1000 \mathrm{ppm} \mathrm{H}_{2}$ and solid black lines without the presence of $\mathrm{H}_{2}$ ). Inlet gas composition: $500 \mathrm{ppm} \mathrm{NO}, 1500 \mathrm{ppm} \mathrm{C}_{2}, 10 \% \mathrm{O}_{2}, 5 \% \mathrm{H}_{2} \mathrm{O}$, Ar-balance. C/N ratio of $6, \mathrm{GHSV}=33,400 \mathrm{~h}^{-1}$.

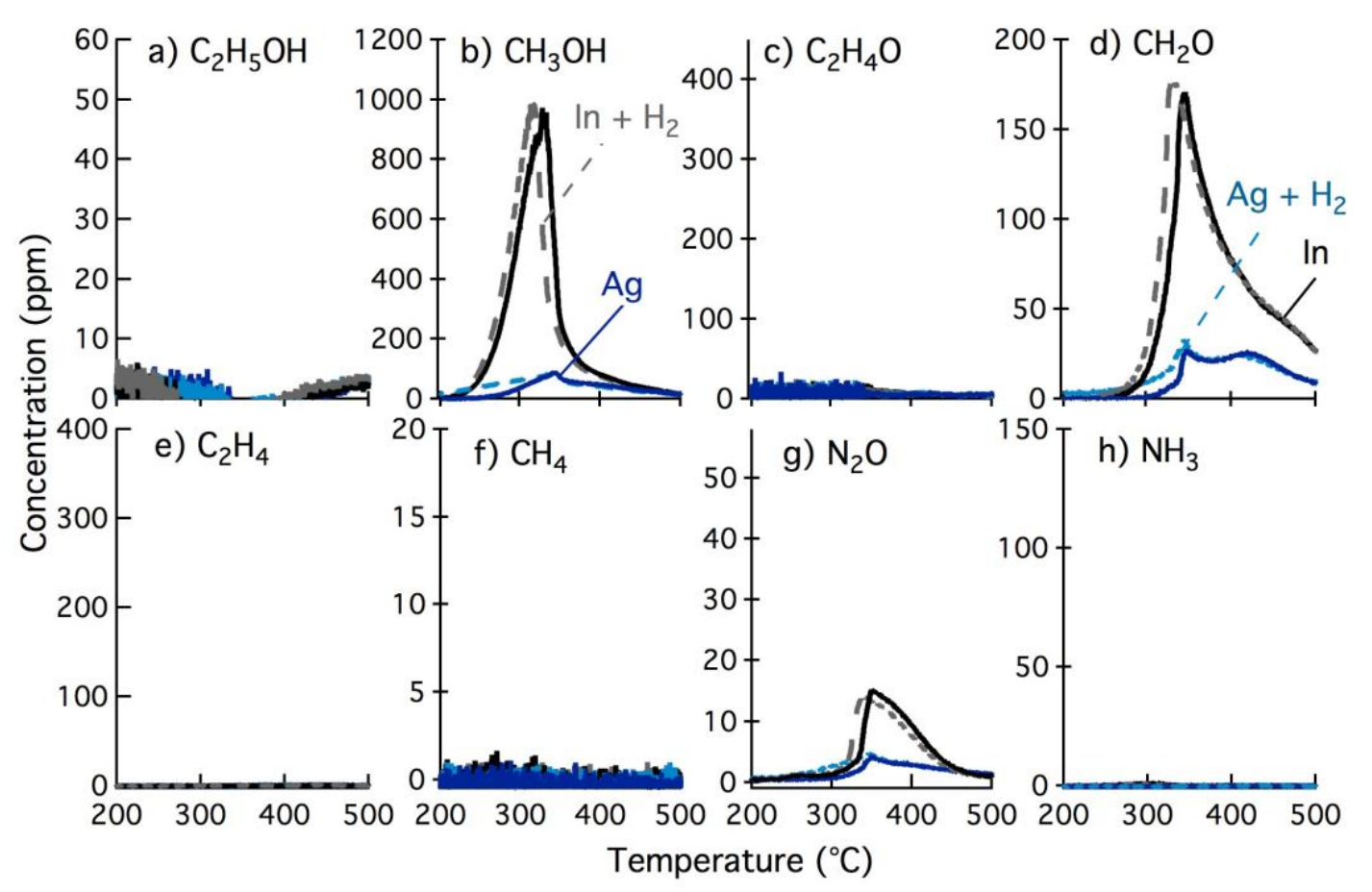

Fig. 10: SCR with DME as reductant. Formation of a) ethanol, b) methanol, c) acetaldehyde, d) formaldehyde, e) ethene, f) methane, g) nitric oxide and $\mathrm{h}$ ) ammonia over $\mathrm{Ag} / \mathrm{Al}_{2} \mathrm{O}_{3}$ (dashed light blue lines are with the presence of $1000 \mathrm{ppm} \mathrm{H}_{2}$ and solid dark blue lines without the presence of $\mathrm{H}_{2}$ ), and $\mathrm{In} / \mathrm{Al}_{2} \mathrm{O}_{3}$ (dashed grey lines are with the presence of $1000 \mathrm{ppm} \mathrm{H}_{2}$ and solid black lines without the 
presence of $\mathrm{H}_{2}$ ). Inlet gas composition: $500 \mathrm{ppm} \mathrm{NO}, 1500 \mathrm{ppm} \mathrm{C}_{2}, 10 \% \mathrm{O}_{2}, 5 \% \mathrm{H}_{2} \mathrm{O}$, Ar-balance. C/N ratio of $6, \mathrm{GHSV}=33,400 \mathrm{~h}^{-1}$.

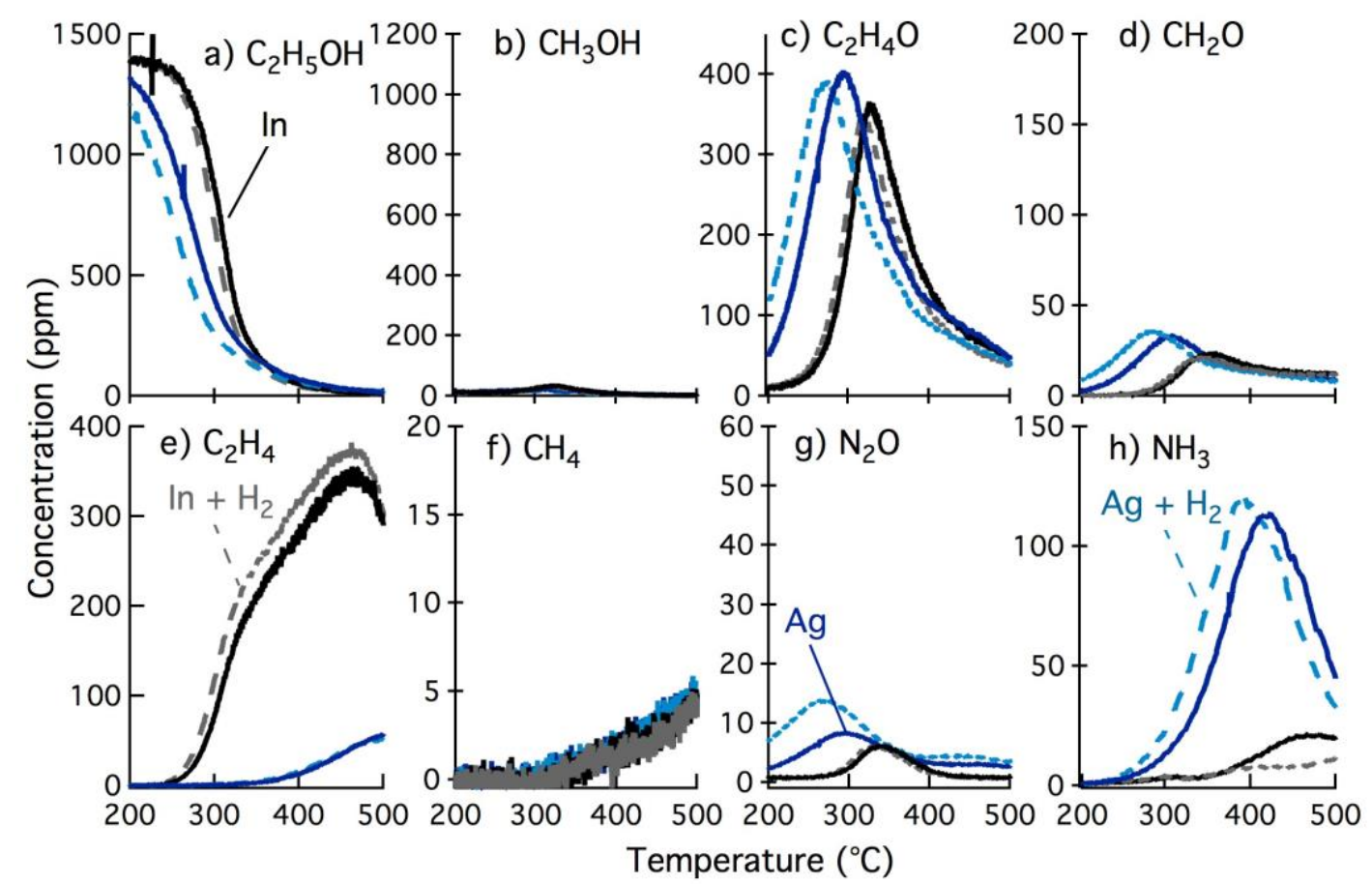

Fig. 11: SCR with ethanol as reductant. Formation of a) ethanol (note that this is the reductant), b) methanol, c) acetaldehyde, d) formaldehyde, e) ethene, f) methane, g) nitric oxide and h) ammonia over $\mathrm{Ag} / \mathrm{Al}_{2} \mathrm{O}_{3}$ (dashed light blue lines are with the presence of $1000 \mathrm{ppm} \mathrm{H}_{2}$ and solid dark blue lines without the presence of $\mathrm{H}_{2}$ ), and $\mathrm{In} / \mathrm{Al}_{2} \mathrm{O}_{3}$ (dashed grey lines are with the presence of $1000 \mathrm{ppm} \mathrm{H}_{2}$ and solid black lines without the presence of $\mathrm{H}_{2}$ ). Inlet gas composition: $500 \mathrm{ppm} \mathrm{NO}, 1500 \mathrm{ppm} \mathrm{C}_{2}, 10 \% \mathrm{O}_{2}, 5 \%$ $\mathrm{H}_{2} \mathrm{O}$, Ar-balance. C/N ratio of $6, \mathrm{GHSV}=33,400 \mathrm{~h}^{-1}$.
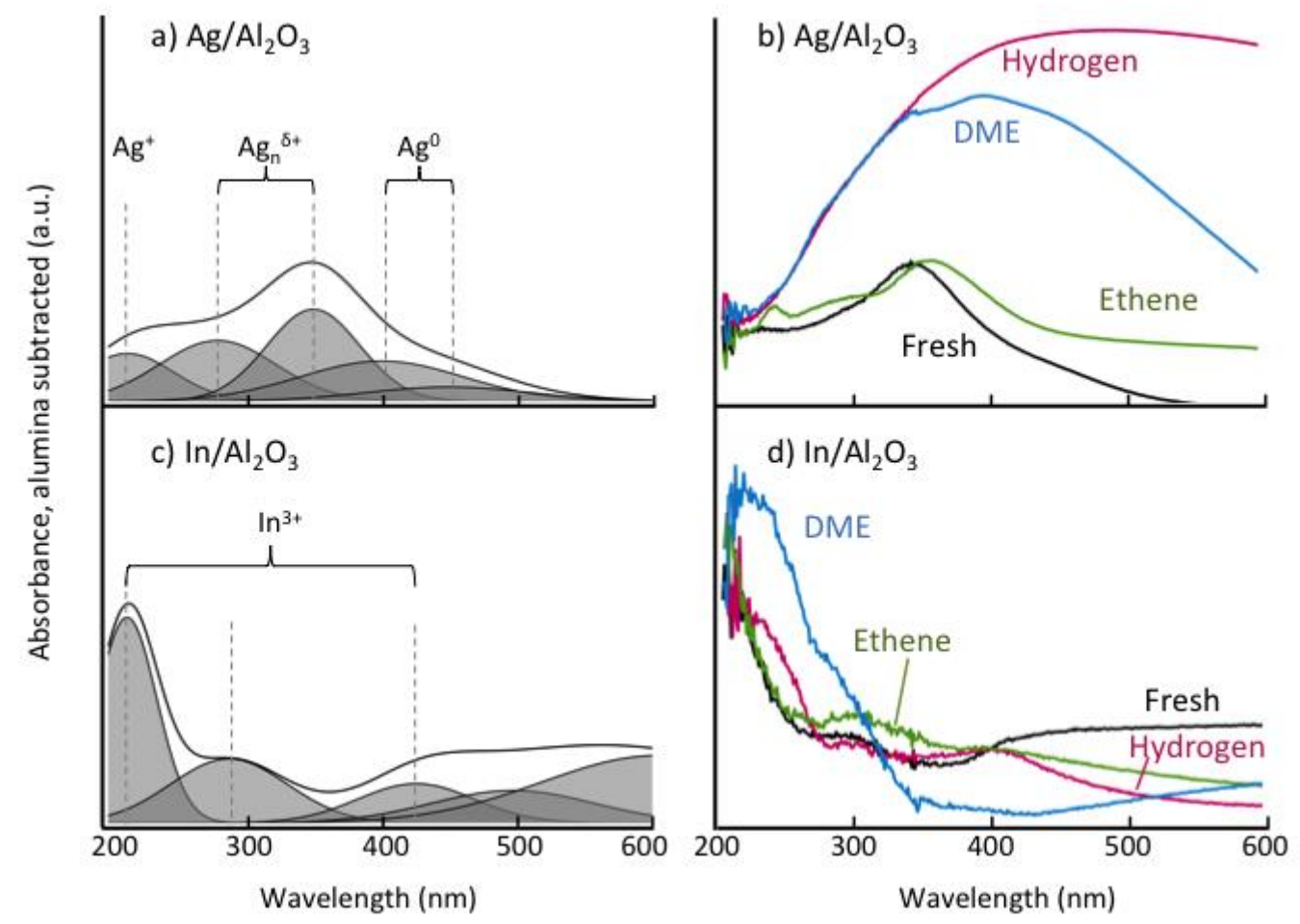
Fig. 12: UV-Vis spectra of $\mathrm{Ag} / \mathrm{Al}_{2} \mathrm{O}_{3}$ (a and b) and $\mathrm{In} / \mathrm{Al}_{2} \mathrm{O}_{3}$ (c and d). The left panel shows deconvoluted spectra for the fresh samples while the right panel shows spectra after pretreatment in $400^{\circ} \mathrm{C}$ with 1000 ppm hydrogen (red lines), $500 \mathrm{ppm}$ DME (blue lines) and $500 \mathrm{ppm}$ ethene (green lines), respectively. 